\title{
CONTRIBUTION TO THE KNOWLEDGE OF HEMIAUCHENIA PARADOXA (ARTIODACTYLA, CAMELIDAE) FROM THE PLEISTOCENE OF SOUTHERN BRAZIL
}

\author{
CAROLINA SALDANHA SCHERER, JORGE FERIGOLO, ANA MARIA RIBEIRO \\ Museu de Ciências Naturais, FZB/RS, Av. Salvador França, 1427, 90690-00, Porto Alegre, RS, Brazil. \\ carolina_scherer@yahoo.com.br,jorge.ferigolo@fzb.rs.gov.br,ana.ribeiro@fzb.rs.gov.br \\ CÁSTOR CARTELLE GUERRA \\ Museu de Ciências Naturais, PUCMG, Av. Dom José Gaspar, 290, 30535-610, Belo Horizonte, MG, Brazil. \\ cartelle@pucminas.br
}

\begin{abstract}
A description of the dentition and anterior and posterior limbs of new specimens of Hemiauchenia paradoxa Gervais \& Ameghino is presented. The materials come from Santa Vitória do Palmar, Uruguaiana, Alegrete, Itaqui and Dom Pedrito municipalities in the Rio Grande do Sul State, southern Brazil. New characters supporting distinction between Hemiauchenia paradoxa and Palaeolama major Liais in the dental morphology and limb dimensions, are here presented: proportions of the mandible, morphology of the lingual lophs and labial lophids of molar teeth, size of protostylid and parastylid of the molars and the proportions of distal segments of limbs. Studies with material of other South American regions could contribute for the distinction between these taxa, and between the others camels of South American Pleistocene.
\end{abstract}

Key words: Hemiauchenia paradoxa, Camelidae, Artiodactyla, Pleistocene, Rio Grande do Sul State, Brazil.

RESUMO - É aqui apresentado a descrição da dentição e de membros anteriores e posteriores de novos espécimes de Hemiauchenia paradoxa Gervais \& Ameghino. Os materiais são provenientes dos municípios de Santa Vitória do Palmar, Uruguaiana, Alegrete, Itaqui e Dom Pedrito no Rio Grande do Sul, sul do Brasil. Novos caracteres que suportam a distinção entre Hemiauchenia paradoxa e Palaeolama major Liais na morfologia dentária e dimensões pós-cranianas são aqui apresentados: proporções da mandíbula, morfologia dos lofos linguais e lófidos labiais nos dentes molares, tamanho do protostilido e parastilido nos molares e proporções dos segmentos distais dos membros. Estudos com material de outras regiões da América do Sul poderão melhor contribuir para a distinção entre estes táxons, bem como entre os demais camelídeos do Pleistoceno sul-americano.

Palavras-chave: Hemiauchenia paradoxa, Camelidae, Artiodactyla, Pleistoceno, Rio Grande do Sul, Brasil.

\section{INTRODUCTION}

The earliest record of Camelidae is from the Eocene of North America and forms similar to living camelids are known from the end of the Miocene (Pires-Ferreira, 1982). With the elevation of the Isthmus of Panama in the late Pliocene, some Lamini forms (Hemiauchenia $\mathrm{H}$. Gervais \& Ameghino, 1880 and Palaeolama P. Gervais, 1867) migrated to South America, where they radiated (Webb, 1974).

According to Webb \& Stehli (1995), the genera that migrated to South America were Palaeolama and Hemiauchenia. However, Cione \& Tonni (1995) consider that the oldest South American remains of Camelidae are of Lama Frisch, 1775, in the Pampean region of Argentina, Marplatan Age, Barrancalobian sub-Age. Hemiauchenia was registered for the Ensenadan, Bonaerian and Lujanian Ages in Argentina and Uruguay (Menegaz \& Ortiz-Jaureguizar, 1995;
Cione \& Tonni 1995, 1999; Cione et al., 1999; Ubilla \& Perea, 1999; Ubilla, 2004), and Palaeolama from Ensenadan of Bolivia (Marshall et al., 1984; MacFadden \& Shockey, 1997) and the Lujanian of Brazil, Chile, Peru, Venezuela, Bolivia, Ecuador and Paraguay (Marshall et al., 1984; Cartelle et al., 1989).

Hemiauchenia paradoxa $\mathrm{H}$. Gervais \& Ameghino, 1880 was synonymized with Hemiauchenia major (Liais, 1872) by López-Aranguren (1930) and with Palaeolama weddelli P. Gervais, 1855 by Cabrera $(1931,1935)$. Hoffstetter (1952) however, revalidated the species and included it in the genus Palaeolama. Webb (1974) considered valid the genera Hemiauchenia and Palaeolama, recognizing H. paradoxa for Argentina and $H$. major for Northeastern Brazil. Most authors rejected this proposition, considering the Brazilian species as actually being Palaeolama major (e. g., SouzaCunha, 1966; Cartelle et al., 1989; Guérin et al., 1990; Bergqvist, 1993). Following the work of Webb (1974), many authors from 
Argentina and Uruguay considered the species $H$. paradoxa as valid. However, Cartelle $(1992,1999)$ questioned the validity of H. paradoxa and P. major, suggesting that the supposed differences can be interpreted mainly as intraspecific variations.

In the late Pleistocene of Minas Gerais, Ceará, Paraíba, Rio Grande do Norte, Pernambuco, Bahia, Piauí, Sergipe, Mato Grosso do Sul and Acre States the only species registered was P. major (Winge, 1906; Souza-Cunha, 1966; Rolim, 1974; PaulaCouto, 1980; Cartelle et al., 1989; Guérin et al., 1990; Bergqvist, 1993; Rancy, 1993; Góes et al., 2002; Salles et al., 2003).

In the Rio Grande do Sul State (RS), few are the works dealing with fossil camelids. Souza-Cunha (1959) described three molars of Palaeolama paradoxa from Santa Vitória do Palmar Municipality. Bombim (1976) referred P. paradoxa and Lama guanicoe (Muller, 1776) for the Touro Passo creek. Oliveira (1992) described a mandible and teeth coming from the Touro Passo creek, Sanga Borba (Pantano Grande Municipality) and Chuí (Santa Vitória do Palmar) as Hemiauchenia paradoxa. Buchmann $(1994,2002)$ referred remains of Palaeolama paradoxa and Lama for the Coastal Plain. Scherer et al. $(2004,2005)$ identified new material from Santa Vitória do Palmar, Uruguaiana (Touro Passo creek), Alegrete (Sanga da Cruz creek) and Itaqui municipalities as two forms, a large one, Palaeolama, and a smaller one, Lama. Later (Scherer et al., 2006), attributed the large size postcranial material to Palaeolama major, in following the taxonomic classification of Cartelle $(1992,1999)$, who considered this species as the only valid large species for the Pleistocene and Holocene from Brazil and Argentina. In the same work, the dental and some postcranial material was attributed to Camelidae indeterminate, because it presented many significant differences with P. major.

This work describes the fossil remains of Hemiauchenia paradoxa for the Pleistocene of Rio Grande do Sul State, and discusses some dental characters and postcranial proportions important for the differentiation of this taxon from other South American camelids.

\section{GEOLOGICAL SETTING}

The fossil camelids of Rio Grande do Sul State (RS) come from Uruguaiana (Touro Passo creek), Alegrete (Sanga da Cruz creek) and Santa Vitória do Palmar (Hermenegildo Beach, Coastal Plain), Itaqui and Dom Pedrito Municipalities (Figure 1A).

The Touro Passo creek is $13 \mathrm{Km}$ to the north of Uruguaiana City (Da Rosa, 2003), and according Bombim (1976) from a geological point of view, the best studied area is at $56^{\circ} 50^{\prime} \mathrm{W}$ and $29^{\circ} 40^{\prime} \mathrm{S}$. The same author collected the first fossil mammals, possibly from the point that he called "place with larger number of mammals", in the carbonate level (medium portion of the "Mudstone Member"). The material from the carbonate level has expanded dimensions, with a lot of superficial fractures, due to substitution and/or impregnation by $\mathrm{CaCO} 3$ or due to rizoconcretion formation posterior to fossilization. Other Camelidae fossils come from another point of the creek, of the outcrop "Ponte Velha", with or without carbonate concretions.

Bombim (1976) defined the Touro Passo Formation as being fluvial deposits of the flood plain of a homonym stream, presenting a conglomeratic facies (Conglomeratic Member), deposited during a flood, and covered by a muddy sandstone facies (Mudstone Member) with levels of $\mathrm{CaCO} 3$, developed in the consequent flood plain. According to him, each member would be composed by only one layer, deposited during a short time interval, having an absolute age of $11.010 \pm 190$ years BP $\left(\mathrm{C}^{14}\right)$ (Mudstone Member). Oliveira \& Lavina (2000) proposed that the members defined by Bombim (1976) would just be local episodes of sedimentation.

Milder (2000) accomplished new thermoluminescence dating in a ravine where mollusks were collected (Cinco Palmas Farm), yielding: 6.400 years BP for the black soils; 15.400 years BP for the medium portion of the muddy sandstones facies; 42.600 years BP for the base of this facies (Figure 1B); and 16.327 years BP in Bombim's (1976) "more fossiliferous place" (middle portion of the muddy sandstone facies). Kotzian et al. (2005) accomplished ${ }^{14} \mathrm{C}$ ages for the mollusks encountered in the medium portion of the muddy sandstone facies, resulting in $15.970 \pm 90$ years BP and 16.650 \pm 203 years BP, which approach the thermoluminescence data obtained by Milder (2000).

Sanga da Cruz creek is a small drainage of Ibicuí River, $23 \mathrm{~km}$ north to Alegrete City, S29 $34^{\prime} 08^{\prime \prime}$ and W55 $42^{\prime} 36^{\prime \prime}$ (Da Rosa, 2003; Scherer \& Da Rosa, 2004).

Fossil mammals were collected during archaeological excavations, in the conglomeratic Salatiel II outcrop (an old terrace of Ibicuí River, now cut by the actual drainage, the Sanga da Cruz), in the right margin of Sanga da Cruz creek. The fossils found in this outcrop present ocher color, due to preservation with ferrous material. Most fossils are incomplete and isolated, suggesting reworking postfossilization (Scherer \& Da Rosa, 2004).

The outcrops of Sanga da Cruz creek present a lithology composed of a conglomeratic level at its base, where fossils mammals are collected, covered by a muddy sandstone level, with archaeological material (Da Rosa, 2003).

The Sanga da Cruz fauna was dated $\left({ }^{14} \mathrm{C}\right)$ by Miller $(1987)$ in two levels, one with $17,830 \pm 100,17,850 \pm 190$ and 19,350 years BP, where were collected Macrauchenia and other extinct forms, like Propaopus, Pampatherium and Glyptodon cingulates; and another level with 12,770 years BP, with remains of Hippidion and Hemiauchenia. Milder (2000) distinguished three stratigraphic levels at the Salatiel II outcrop, for which was accomplished thermoluminescence dating: $11.740 \pm 600$ for the clay siltstone, $13.800 \pm 800$ for the muddy sandstone facies and $14.830 \pm 750$ and $14.925 \pm 800$ for the fossiliferous conglomeratic basal facies (Figure 1C).

Oliveira (1992) grouped together the local faunas of Sanga da Cruz creek, Quaraí River and Touro Passo creek, considering all to be of Lujanian age (South America Land Mammal Age). Da Rosa (2003) emphasized the lithologic, faunistic and the absolute age similarities, between the Touro Passo creek, Quaraí River and Sanga da Cruz creek outcrops, 

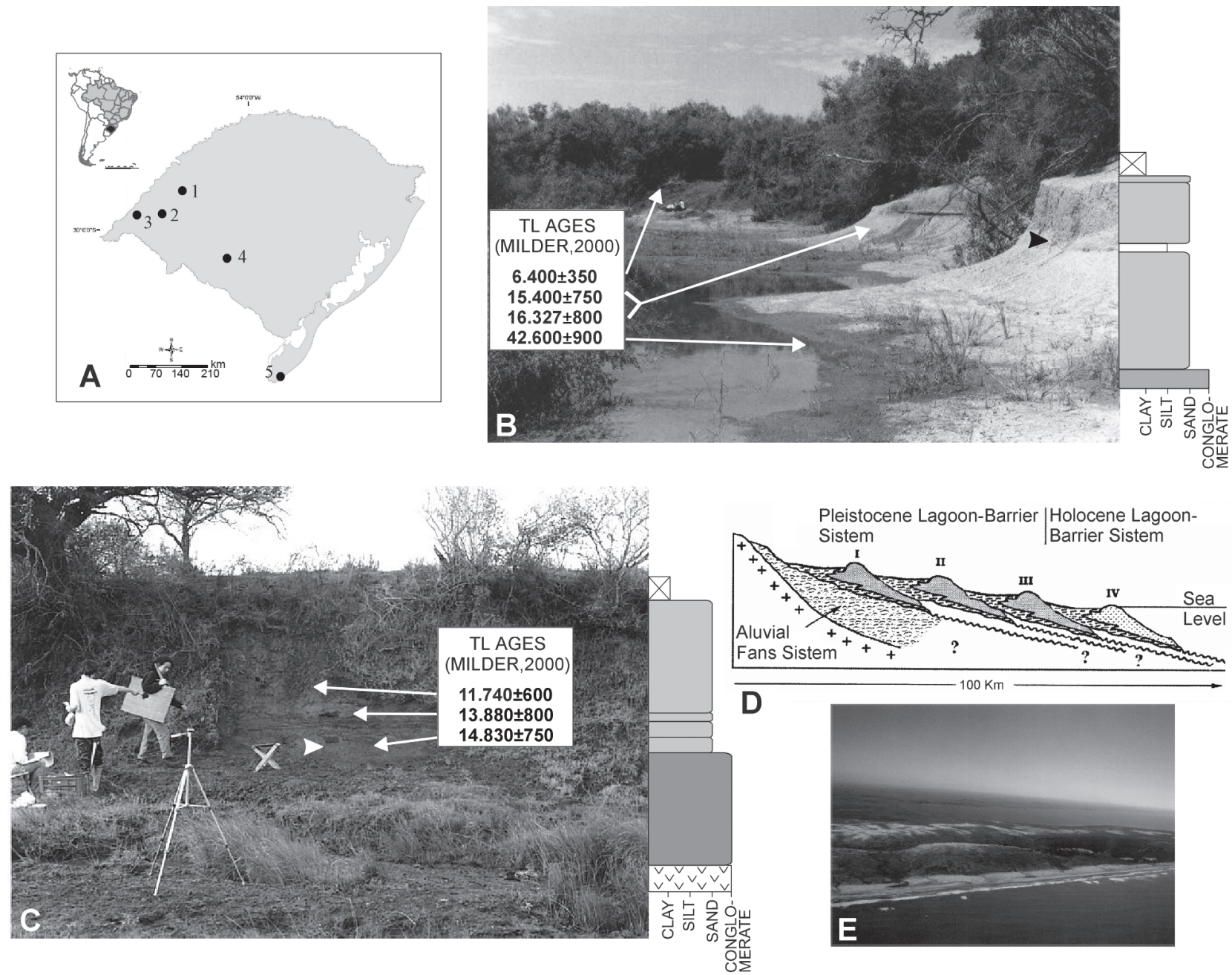

Figure 1. A, Localization of the outcrops where fossil camelids were colected in Rio Grande do Sul State: 1, Itaqui; 2, Alegrete (Sanga da Cruz creek); 3, Uruguaiana (Touro Passo creek); 4, Dom Pedrito; 5, Santa Vitória do Palmar (Hermenegildo beach); B, stratigraphy and TL ages of Touro Passo creek (Da Rosa, 2003); C, stratigraphy and TL ages of Sanga da Cruz creek (Da Rosa, 2003); Arrows in B and C indicate the fossiliferous level; D, stratigraphy of Coastal Plain RS deposits (Tomazeli \& Villwock, 2000); E, overview of Hermenegildo beach (photo by F. Buchmann);

all equally having a basal conglomerate and a muddy sandstone at the top. This deposition occurred in a considerable area which included from the West of Rio Grande do Sul State to the North of Uruguay, as well as the Northeast of Argentina. As mentioned by this author, the Touro Passo creek, Quaraí River and Sanga da Cruz creek have a similar deposition during the same period of time (Lujanian), last 45.000 years.

The Hermenegildo Beach $\left(53^{\circ} 15^{\prime} \mathrm{S}, 33^{\circ} 42^{\prime} \mathrm{W}\right)$ is in the southern coastal plain of the Rio Grande do Sul State, far 20 $\mathrm{km}$ from Santa Vitória do Palmar city.

The coastal plain of Rio Grande do Sul had its origin related to the Atlantic Ocean opening, in the early Cretaceous. Since then, it has suffered modifications in its landscape according to sea level fluctuations, which would have developed the lateral juxtaposition of a depositional system of alluvial fans, and four systems of lagoon-barrier (Villwock \& Tomazelli, 1995). The first is composed of sedimentary facies formed by the gravity flow of sediments inside the Coastal Plain. The four lagoon-barrier systems were formed starting from four transgressive-regressive events: systems I, II and III of Pleistocene age and System IV of Holocene age (Figura 1D).

The fossils studied were collected along the shoreline of the "Hermenegildo Beach", and they come from the Hermenegildo's parcel, associated with the deposits of the Lagoon-Barrier System III (Figura 1D). These fossils are rolled and collected at the beach, being similar to those from Arroio Chuí, and associated to marine fossils (Ribeiro et al., 1998). They present dark coloration, high density and carbonate cement, suggesting reworking by the marine ambient (Lopes et al., 2001). After the deposition in lagoonal ambient (probably the Lagoon III), posterior to the fossilization process, they were reworked and cemented by calcium carbonate in a marine shore environment and preserved in sandstones and carbonate in the parcels and submerged banks (foreshore and continental platform). Later, they were exposed to weathering, when there was recrystalization of the carbonate in fresh water. The fossils presently rolled in 

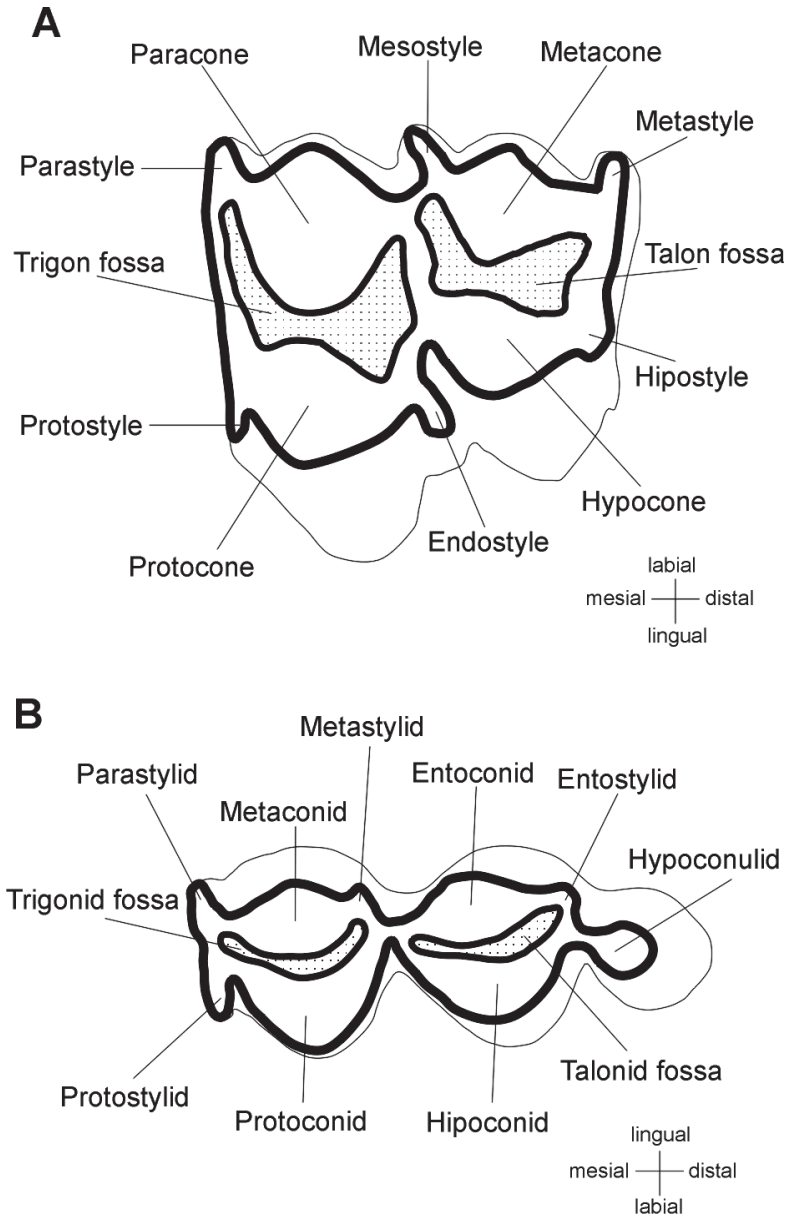

Figure 2. Dental morphology and terminology in the upper (A) and lower (B) left third molars of camelidae (according to Hershkovitz, 1982).

the coastline are from several source-areas that were formed of old atrand lines, and transported due to the action of present hydrodynamic processes (Buchmann, 1994, 2002). Some authors that studied such fossils (e. g. Oliveira, 1992, Oliveira \& Pereira, 2006) considered that they are a mixture of taxa of the Pampean and Intertropical areas. However, it is not possible to exclude the hypothesis of an endemic fauna in this region, since current studies (e.g. Noriega et al., 2003) indicate the occurrence of an endemic fauna in areas of the same latitude.

There are no data at all about some specimens that are from much before the Museu de Ciências Naturais foundation. A few others (from Itaqui and Dom Pedrito Municipalities) lack geological data because were carried to the Museum by landholders.

\section{MATERIAL AND METHODS}

The material is deposited in the Paleovertebrates Collection of Museu de Ciências Naturais da Fundação Zoobotânica do Rio Grande do Sul and Laboratório de Estratigrafia e Paleobiologia da Universidade Federal de Santa Maria. The material was compared with recent and fossil specimens of the collections of the Museu de Ciências Naturais of the Pontifícia Universidade Católica de Minas Gerais, Museo de La Plata, Museo Argentino de Ciencias Naturales Bernardino Rivadavia and Museu de Ciências Naturais da Fundação Zoobotânica do Rio Grande do Sul.

The bone terminology follows Webb (1965), Sisson \& Grossman (1985) and the Nomina Anatomica Veternaria (1983), whenever possible. The dental terminology (Figure 2) follows Hershkovitz (1982). The systematic follows Webb (1974).

Abbreviations. UFSM, paleovertebrate collection of the Laboratório de Estratigrafia e Paleobiologia da Universidade Federal de Santa Maria, Santa Maria; MCN-PV, paleovertebrate collection, Museu de Ciências Naturais of the Fundação Zoobotânica do Rio Grande do Sul, Porto Alegre; MCN-M, MCL, collections of mammals and paleovertebrates, Museu de Ciências Naturais, Pontifícia Universidade Católica de Minas Gerais, Belo Horizonte; MLP, Museo de La Plata, La Plata; MACN, paleovertebrate collection of the Museo Argentino de Ciencias Naturales Bernardino Rivadavia, Buenos Aires; MCN-M, mammal collection, Museu de Ciências Naturais da Fundação Zoobotânica do Rio Grande do Sul, Porto Alegre.

\section{SYSTEMATIC PALEONTOLOGY}

\author{
Order ARTIODACTYLA Owen, 1848 \\ Suborder TYLOPODA Illiger, 1811 \\ Family CAMELIDAE Gray, 1821 \\ Subfamily CAMELINAE Zittel, 1893 \\ Tribe LAMINI Webb, 1974 \\ Hemiauchenia $\mathrm{H}$. Gervais \& Ameghino, 1880 \\ Hemiauchenia paradoxa H. Gervais \& Ameghino, 1880
}

(Figures 3-9, Tables 1-13)

Materials. Touro Passo creek: MCN-PV 3267, incomplete right maxilla; MCN-PV 1471, left dentary; MCN-PV 2077, right dentary; MCN-PV 6946, left incomplete dentary (juvenile); MCN-PV 1465, right $\mathrm{M}^{3}$; MCN-PV 1474b, right $\mathrm{M}_{2}$; MCN-PV 1474a, right $\mathrm{M}_{3}$; MCN-PV 2159, 6947, left $\mathrm{M}_{3}$; MCN-PV 2164a-d, incomplete lumbar vertebrae; MCN-PV 7927, sacrum; MCN-PV 1973, 2088, incomplete left humeri; MCN-PV 3334, incomplete right humerus; MCN-PV 1975b, 2082b, incomplete left radius-ulna; MCN-PV 3359, UFSM 11325, incomplete right radius-ulna; MCN-PV 2258a-f, left unciform, scaphoid, magnum, pyramidal, pisiform, trapezoid; MCN-PV 1975a, 2082a, left metacarpals; MCN-PV 3278, incomplete right metacarpal; MCN-PV $2258 \mathrm{~g}$, incomplete left hand proximal phalanx; MCN-PV 1975c, incomplete left femur; MCN-PV 3309, incomplete right femur; MCN-PV 1975d, left tibia; MCN-PV 2079, incomplete left calcaneum. Hermenegildo Beach: MCN-PV 6755, 6795, right $\mathrm{M}^{3} ; \mathrm{MCN}-$ PV 6757, right $\mathrm{M}_{2}$; MCN-PV 6762, 7276, left $\mathrm{M}_{2} ;$ MCN-PV 6970, 7278, 7279, left $\mathrm{M}_{3}$; MCN-PV 6575, incomplete left radius-ulna; MCN-PV 7273, right pyramidal; MCN-PV 7047, left pisiform; MCN-PV 6579, left metacarpal; MCN-PV 1137, right hand proximal phalanx; MCN-PV 2181, 7012-7021, left astragali; MCN-PV 6980, 6982-6984, 7268-7272, right 
A

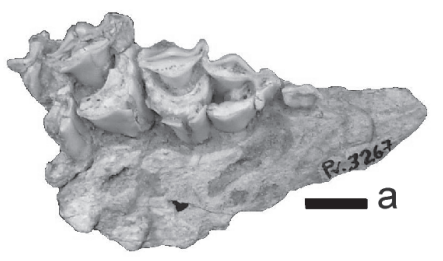

B

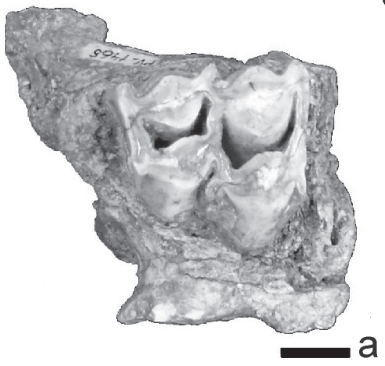

C
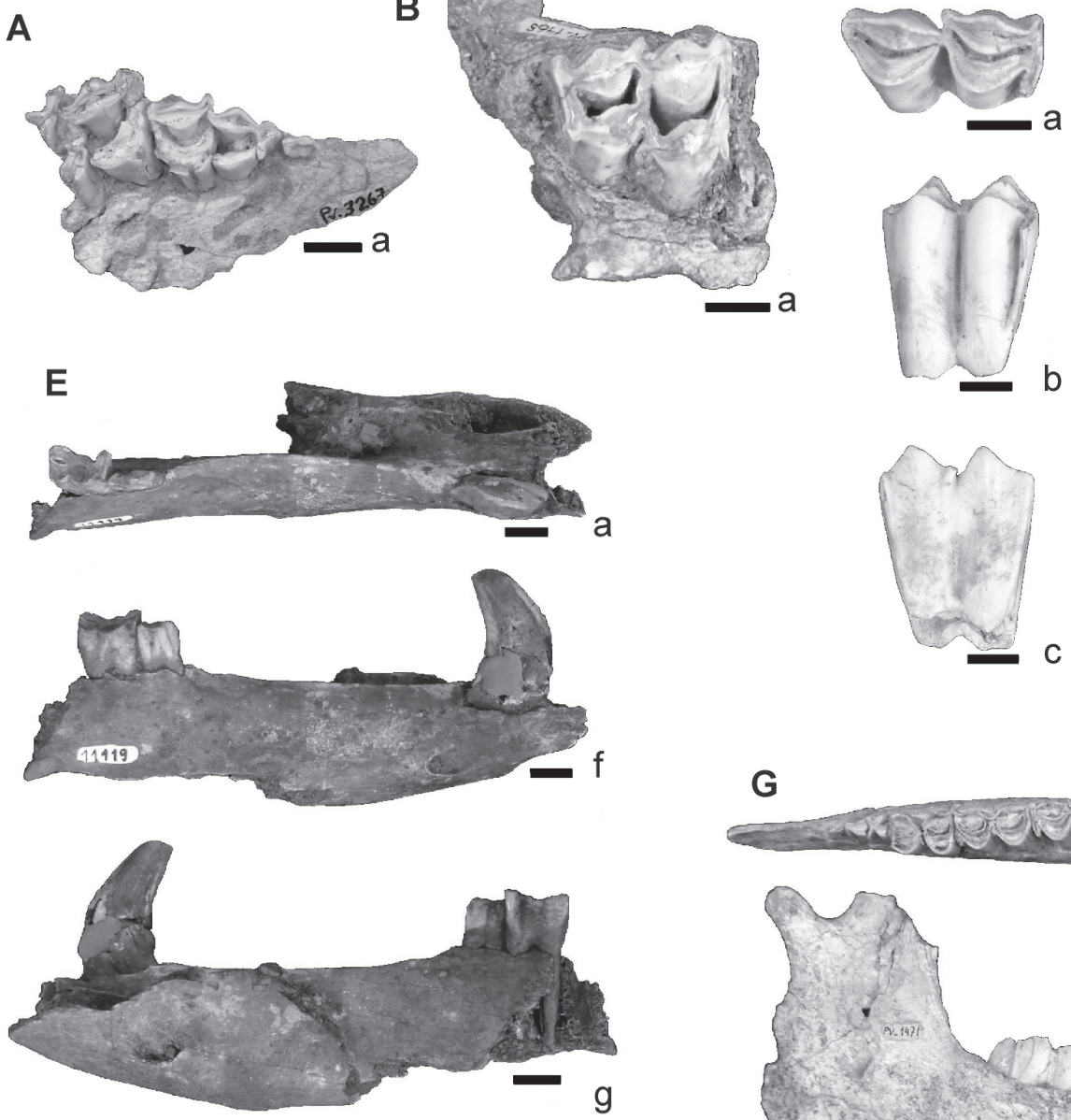

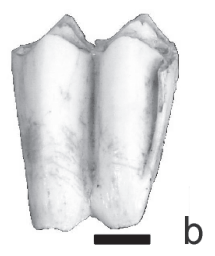

D

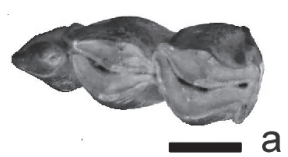

a
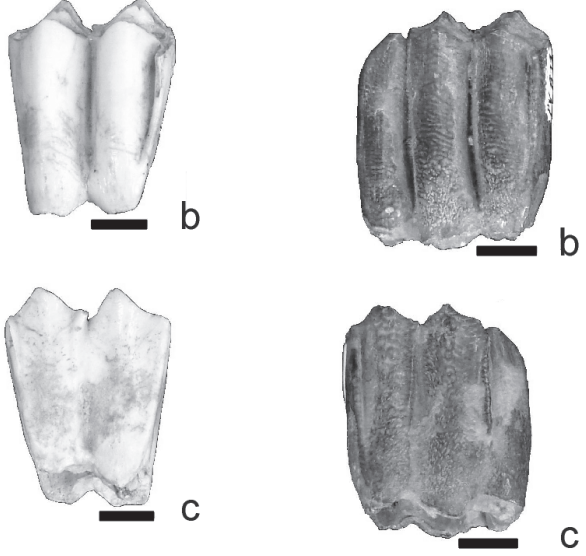
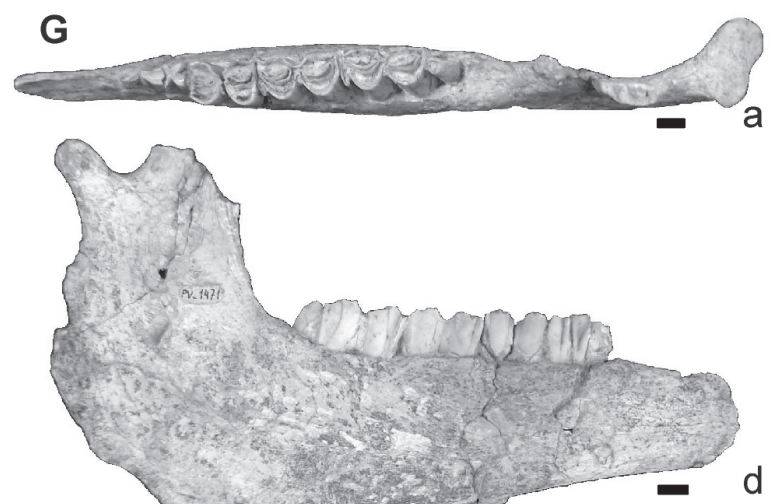

$\mathbf{F}$
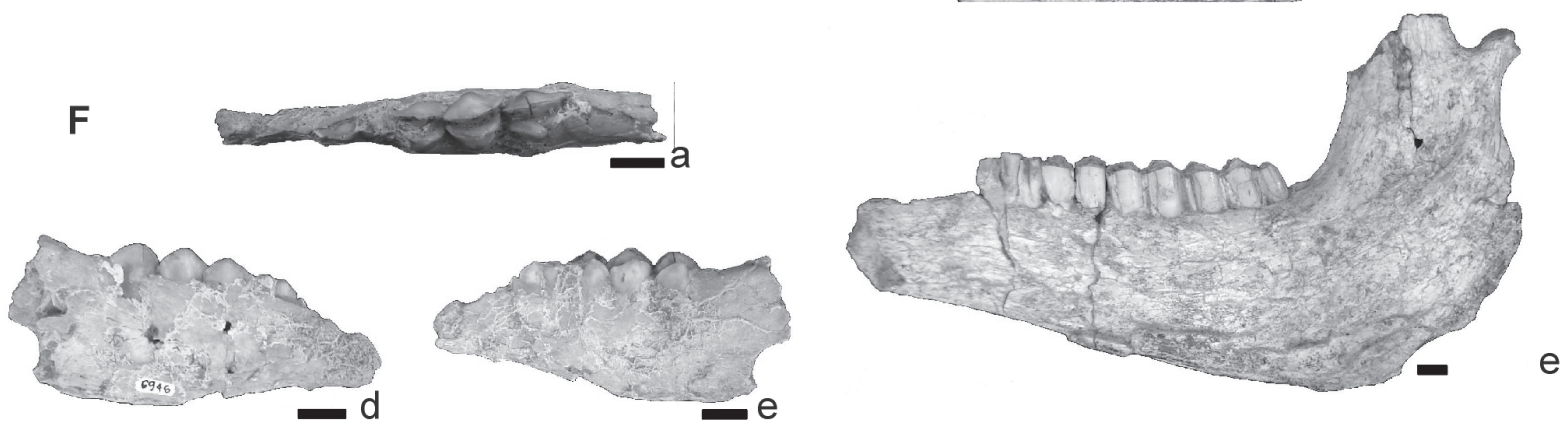

Figure 3. Hemiauchenia paradoxa. A, MCN-PV 3267, fragment of right maxilla; B, MCN-PV 1465, right M³; C, MCN-PV 1474b, right $\mathrm{M}_{2}$; D, MCN-PV 819, right $\mathrm{M}_{3}$; E, MCN-PV 6946, fragment of left dentary; $\mathbf{F}$, MCN-PV 1471, left dentary; G, UFSM 11119, fragment of mandible; in occlusal (a), labial (b), lingual (c), lateral (d), medial (e), right lateral (f) and left lateral $(\mathrm{g})$ views. Scale bars $=1 \mathrm{~cm}$.

astragali; MCN-PV 1163, right calcaneum; MCN-PV 6576, incomplete left calcaneum; MCN-PV 7266, right cuboid. Sanga da Cruz creek: UFSM 11119, incomplete mandible. Dom Pedrito Municipality: MCN-PV 819, right $\mathrm{M}_{3}$. Itaqui Municipality: MCN-PV 3234, left tibia; MCN-PV 3233, incomplete right tibia. Rio Grande do Sul State: MCN-PV 3425 , left $\mathrm{M}_{2}$; MCN-PV 3164, right $\mathrm{M}_{3}$; MCN-PV 3427, incomplete right humerus; MCN-PV 5662, incomplete right tibia; MCN-PV 3037, incomplete left metatarsal.

\section{DESCRIPTION AND DISCUSSION}

Skull. The maxilla (MCN-PV 3267), a right incomplete specimen (Figure 3A) of a juvenile individual, with a $\mathrm{DP}^{2}$ with little wear, $\mathrm{DP}^{3}$, incomplete $\mathrm{DP}^{4}$, both with considerable occlusal wear. The anterior opening of the infraorbital canal is at the level of the mesial half of $\mathrm{DP}^{3}$, and although deformed it has near 6.0 $\mathrm{mm}$ diameter. In the internal face of the maxilla the anteroventral angle of the maxillary sinus was preserved, at the level of $\mathrm{DP}^{3}$. 
Mandible. UFSM 11119 (Figure 3E) is an anterior portion of right dentary with alveolus of $\mathrm{I}_{3}$, the $\mathrm{P}_{3-4}$ and an incomplete $\mathrm{C}_{1}$ The diastema is as long as it is in H. paradoxa (e. $g$. MACN 11072, 11561, MLP 9-2, 9-76) and is longer than in $P$. major (e. g. MCL 058, 6378), but the portion bearing the incisors is lacking. In the left dentary are preserved only the $\mathrm{C}_{1}$ alveolus and the alveolus of $\mathrm{I}_{3}$. The symphyseal region is deep, very long, and narrow, like in H. paradoxa (MACN 11072, MLP 9-2) but larger than in P. major (MCL 058). It is narrower posteriorly, enlarging anteriorly until the level of the $\mathrm{C}_{1}$. The mental foramen has a large diameter $(\sim 13.4 \mathrm{~mm})$ and is at the posteroventral third of the $\mathrm{C}_{1}$ alveolus. This specimen was previously attributed to $P$. major (Scherer et al., 2006), following the hypothesis of Cartelle (1999). However, comparisons with the specimens of H. paradoxa, from Argentina, show several characters in common, cited above, which are different from P. major of intertropical Brazil.

MCN-PV 6946 (Figure 3F) is an incomplete left dentary of a juvenile individual, with $\mathrm{DP}_{3}$ and $\mathrm{DP}_{4}$ with little wear, portion of the diastema and the ascending margin of the alveolar process. The diastemal margin is very thin, and the alveolar process is thick and rounded. The ventral margin is as thin as is the diastema margin. The medial surface of the body is almost flat, whereas the lateral surface is convex.

MCN-PV 1471 (Figure 3G), body of dentary, is near $H$. paradoxa (e. g. MCL 9-474; Cabrera, 1935), and relatively thin and deeper (about 35 percent) than in P. major (e. g. MCL 6378; Cartelle, 1992). Webb (1974) observed the larger depth of the mandible in Hemiauchenia, and attributed this to the more hypsodont molars in this species. Cabrera (1935) and Cartelle (1992) considered this difference as a variation. At the level of the diastema, the dorsal margin is extremely thin (less than $2.0 \mathrm{~mm}$ ). The ventral margin is thick becoming gradually thinner towards the angular process. The margin is concave anteriorly at the level of the diastema and premolars [although much less than in P. major (e. g. MCL 6378)] and slightly convex posteriorly. The diastemal and ventral margins are almost parallel, very similar to H. paradoxa (e. g. MLP 92; MACN 11072), whereas in P. major (MCL 6378) the ventral margin is ascending, so that anteriorly the dentary and the symphyseal region as well are very low.

The coronoid process bears a very wide base, at least three times the condylar process base. The condylar process is low, with a triangular section and a flat posterior surface that extends ventrally for the posterior margin of the dentary ramus towards the dorsal limit of the angular process (fractured). The condyle is transversely wide and dorsally convex and has two portions, an anteriorly inclined oval, continuous with the neck of the condyle; and the other one is a triangular and posteriorly inclined portion, forming a sharp angle with its posterior surface. The articular facet can not be distinguished. The mandibular notch is shallow, extending ventrally for about $15.0 \mathrm{~mm}$, starting from the dorsal margin of the condyle towards the level of the neck. The preserved portion of the angular process shows a rounded and very wide margin, surpassing the posterior limit of the condylar process, the ventral limit of this region being less marked than P. major. The masseteric fossa is deep and anteroposteriorly narrow, and there is not a well defined anterior limit, but its posterior limit is a rounded crest, continuous with the condylar process, like in H. paradoxa, and much more marked than in P. major. The alveolar process is long and posteriorly narrow, being continuous with the anterior margin of the dentary ramus, so that the $\mathrm{M}_{3}$ is more distant from the coronoid process, like in H. paradoxa (e. g. MLP 9-2 and MACN 11072). The mandibular foramen is at the level of the alveolar margin, at the middle of the dentary ramus.

\section{Dentition}

Upper deciduous dentition. The $\mathrm{DP}^{2}$ (MCN-PV 3267; Figure $3 \mathrm{~A})$, is very simple, reduced to two small transversely compressed lobes separated from each other by two narrow entoflexus/ectoflexus. The $\mathrm{DP}^{3}$ is molariform and larger than the $\mathrm{DP}^{2}$, with two lobes, the mesostyle more projected towards the labial surface than the other ectostyles. In the lingual surface, the lophs are U-shaped, being the mesial lobe narrower labiolingually than the distal lobe. The mesial fossa is more elongated and the distal one is more arched. Although with more wear than the $\mathrm{DP}^{4}$, the $\mathrm{DP}^{3}$ is not greatly worn because the protocone and hypocone are not united. The $\mathrm{DP}^{4}$ is similar (molariform) and not much larger than the $\mathrm{DP}^{3}$, and with two lobes (distal lobe incomplete). The protocone and the hypocone are separated. As usual for the upper deciduous teeth, there are no styles between the lobes. The teeth of MCN-PV 3267 are very similar to those of P. major, mainly to the specimens from Toca dos Ossos (Bahia, Brazil) described by Cartelle (1992). However, the $\mathrm{DP}^{3}$ and $\mathrm{DP}^{4}$ are wider than these specimens as well as those figured by Winge (1906). There were no upper deciduous teeth of $H$. paradoxa in the compared material, but due to size differences with $P$. major and the same provenance of the other cranial and postcranial materials, this material is attributed tentatively to H. paradoxa.

Upper permanent dentition. $\mathrm{All}^{3}$ have a size similar to the already described $H$. paradoxa (Cabrera, 1935), but slightly larger than P. major material (Cartelle, 1992). The mesial lobe is larger than the distal one (large labiolingual diameter). Metastyle, parastyle and mesostyle are very large. The trigon fossa is deep, and slightly triangular. The lingual lophs are Ushaped, different from P. major, where they are V-shaped. This difference in the lingual lophs already was observed by Webb (1974) as a generic difference between Hemiauchenia and Palaeolama (based on North American specimens), but a larger sample of specimens from South America is needed to test this generic difference. There are, however some differences in the MCN-PV 1465 (Figure 3B) lingual surface, where there is a marked endostyle, protostyle and hipostyle, which are not present in the other specimens. In the mesial surface of $\mathrm{MCN}$ PV 6795 there is a small cingulum near to the neck. This specimen was previously attributed to $P$. major (Scherer et al., 2006), following the hypothesis of Cartelle (1999), but through comparisons it was observed that there are some characters in common with $H$. paradoxa, from Argentina. 
Lower deciduous dentition. The $\mathrm{DP}_{3}$ of MCN-PV 2077, 6946 (dentaries, Figure 3F) are very similar to the $\mathrm{P}_{3}$, being compressed transversely and formed by only one lobe. The $\mathrm{DP}_{4}$ is similar to the molariform series, with three lobes. The MCN-PV 2077 is much fractured, and the MCN-PV 6946 presents no wear, with the cusps still separate. Although no diagnostic characters were observed in the lower deciduous teeth, MCN-PV 2077 and MCN-PV 6946 are tentatively attributed to $H$. paradoxa, because they came from the same locality as molar teeth and more diagnostic cranial and postcranial materials, described below.

Lower permanent dentition. The $\mathrm{C}_{1}$ (UFSM 11119; Figure $3 \mathrm{E}$ ) is massive, transversely compressed, distally arched and with elongated transverse section, similar to that of $H$. paradoxa (e. g. MACN 11072). The $\mathrm{P}_{3}$, preserved in the specimens UFSM 11119 and MCN-PV 1471 (Figure 3G), are very simple, reduced to a transversely compressed lobe, with entoflexid and small ectoflexid, and no difference was observed with $H$. paradoxa and Palaeolama. The $\mathrm{P}_{4}$ presents a flexid on the labial and lingual faces, the mesial one form a stylid that extends from the labial to the lingual surface, and the distal one defines the second lobe, in which there is a narrow and elongated fossid, well preserved in UFSM 11119. The MCN-PV 1471 presents interproximal wear between $\mathrm{P}_{4}$ and $\mathrm{P}_{3}$ that reduced the lingual and labial stylids. In the distal lobe of $\mathrm{P}_{4}$, there was wear until the distal limit of the fossid, forming a flexid in the contact with the $M_{1}$. The $\mathrm{P}_{4}$ was used by many authors (e. $g$. Webb, 1974) as a diagnostic character for the species and genus. However, such as was already observed by Cabrera (1931), this tooth is very variable due to the different stages of occlusal wear (Cartelle, 1992). The $\mathrm{P}_{4}$ of the specimens UFSM 11119 and MCN-PV 1471 are very similar to others of $H$. paradoxa (e. g. MLP 9-474), mainly in the size, the presence of the mesial stylid, the fossid just in the distal lobe and a smaller mesial lobe, that gives a triangular shape to the tooth. They differ from those of $P$. major by the larger size, the larger mesial lobe and the absence of the mesial fossid.

The lower molars present similar size to the specimens of $H$. paradoxa. In molars with little or no wear, the cusps are still separated, better observed in the specimens MCN-PV 819 e 1474 b (Figure 3C, D). In the teeth with more occlusal wear, the labial lophids are U-shaped, and protostylid and parastylid are very pronounced, which is found in all specimens of $H$. paradoxa, but not in $P$. major, where the labial lophids are V-shaped and protostylid and parastylid are almost imperceptible (Figure 4). The protostylid and parastylid were not designated as diagnostic by any author,

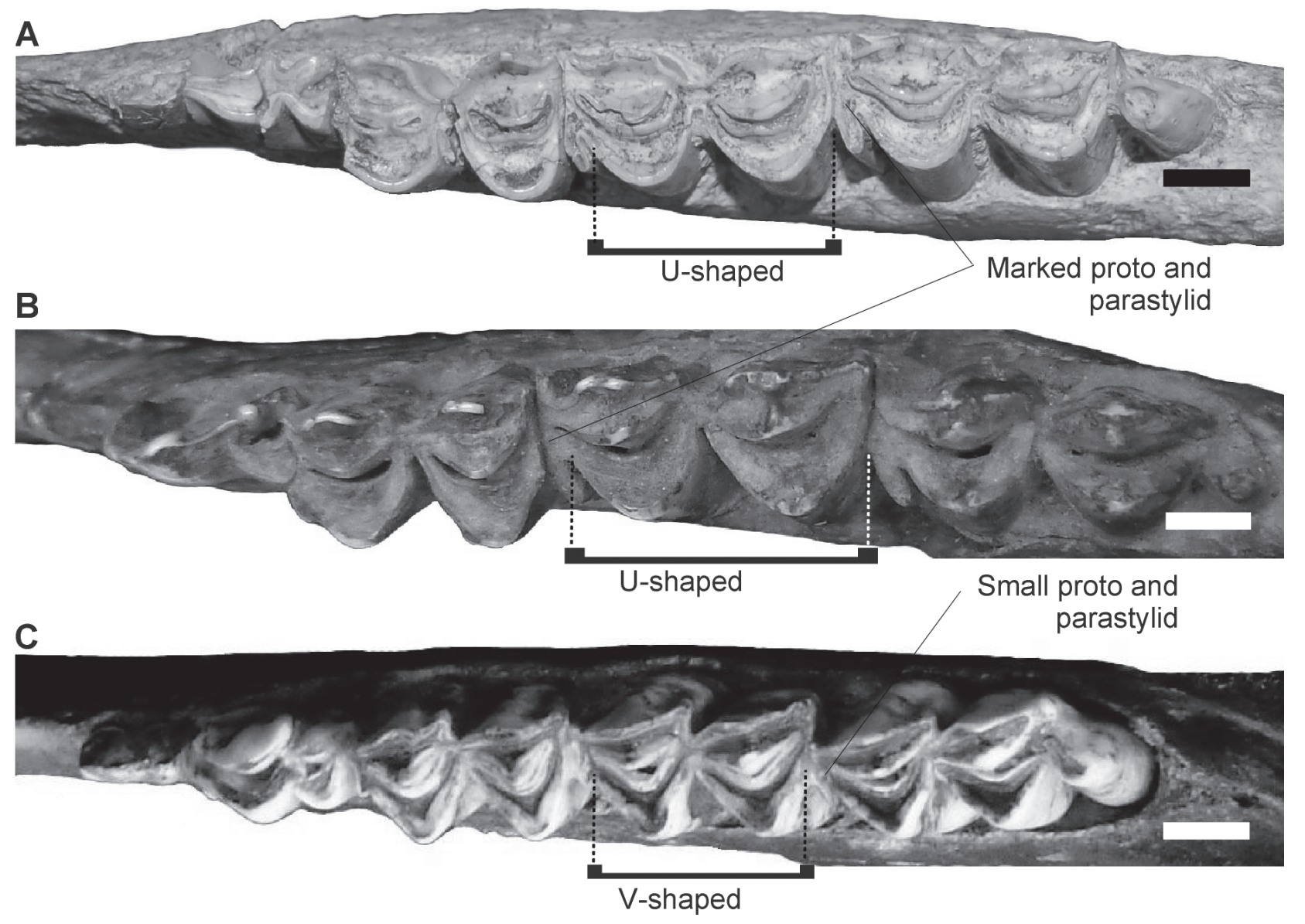

Figure 4. A-B, left dentaries of Hemiauchenia paradoxa in MCN-PV 1471 (A) and MLP 9-474 (B), Cabrera, 1935). C, right dentary of Palaeolama major, MCL 6376, in occlusal view showing the differences in the lower teeth (modified (reversed) from Cartelle,1992). Scale bars $=1 \mathrm{~cm}$. 
Table 1. Measurements $(\mathrm{mm})$ of $H$. paradoxa mandibles Abbreviations: HD, height of dentary in the half lenght of diastema; HMC, height of mandibular condyle starting from the mandibular incisure; $\mathbf{H M}_{1}$, height of dentary at level of $\mathrm{M}_{1} ; \mathbf{H M}_{3}$, height of dentary at level of $M_{3}$; LD, diastema length; LDS, lenght of dental series $P_{3}-$ $M_{3}$; LSR, length of symphysis region; MWC, maximum width of condyle; WD, width of dentary in half lenght of diastema.

\begin{tabular}{c|ccccccccc}
\hline & HD & HMC & HM $_{1}$ & $\mathbf{H M}_{3}$ & LD & LDS & LSR & MWC & WD \\
\hline UFSM & 28.2 & - & - & - & 67.9 & - & 73.2 & - & 12.4 \\
$\mathbf{1 1 1 1 9}$ & 28.2 & & - & & & & & & \\
$\begin{array}{c}\text { MCN-PV } \\
\mathbf{2 0 7 7}\end{array}$ & - & - & - & - & - & 115.0 & - & - & - \\
$\begin{array}{c}\text { MCN-PV } \\
\mathbf{1 4 7 1}\end{array}$ & 32.9 & 15.1 & 46.6 & 63.5 & - & 108.9 & - & 24.0 & 10.7 \\
\hline
\end{tabular}

Table 2. Measurements $(\mathrm{mm})$ of upper teeth of $H$. paradoxa. Abbreviations: DW, distal lobe width; LLW, labiolingual width;MDL, mesiodistal length; MW, mesial lobe width.

\begin{tabular}{l|cccc}
\hline & DW & LLW & MDL & MW \\
\hline MCN-PV 3267 - DP & 14.4 & & 22.8 & 11.0 \\
MCN-PV 3267 - DP & 21.0 & & - & 17.4 \\
MCN-PV 6755 - M & 15.0 & 19.0 & 28.0 & 19.5 \\
MCN-PV 6795 - M & - & - & - & 24.0 \\
MCN-PV 1465 - M & 16.0 & 22.0 & 28.0 & 20.5 \\
\hline
\end{tabular}

but were cited by Cartelle (1992) as less in P. major, and by Cabrera (1935) as very marked in H. paradoxa. The metastylid and entostylid are not very developed, reducing with wear, but differ from P. major that presents stylids only slightly marked in the $\mathrm{M}_{2-3}$. The mesostylid or other interlobular stylids are absent, and the ectoflexids are shallow. The trigonid and talonid fossids are deep, semilunar shaped and mesiodistally prolonged. In some specimens the cementum was preserved. The $\mathrm{M}_{3}$ is characterized by a third distal lobe, formed by the hypoconulid, without formation of a fossid during occlusal wear. Differently from the $\mathrm{M}_{1-2}$, which decrease in length with wear (Cabrera, 1931), the $M_{3}$ maintain a constant length after the roots are completed.

Axial skeleton. In the lumbar vertebrae (Figure 5A), although fractured, the transverse processes and the neural spine are anteroposteriorly elongated. The transverse process lies at the more anterior portion of the vertebral body. The prezygapophysis is remarkably concave (MCN-PV 2164c) and turned medially, whereas correspondently the postzygapophysis is convex (MCN-PV 2164a,b). The vertebral body is slightly flattened dorsoventrally in the posterior face. Posteriorly, the pedicle presents a deep notch, whereas anteriorly, the pedicle extends continuously over the margin of the vertebral body. Due to poor preservation it is not possible to place them in the L1-L5 series. In spite of this, the lumbar vertebrae (MCN-PV 2164a-d) resemble those of $H$. paradoxa.

The sacrum (MCN-PV 7927; Figure 5B) consists of four bodies, four transverse processes, and four neural arches, all them fused in an unique bone, with total length of $170.4 \mathrm{~mm}$. The rugose surface for articulation with the iliac of the first sacral vertebra (S1) is wide (144.4 $\mathrm{mm}$ ) and extends to half the
Table 3. Measurements $(\mathrm{mm})$ of lower teeth of $H$. paradoxa. Abbreviations as in Table 2.

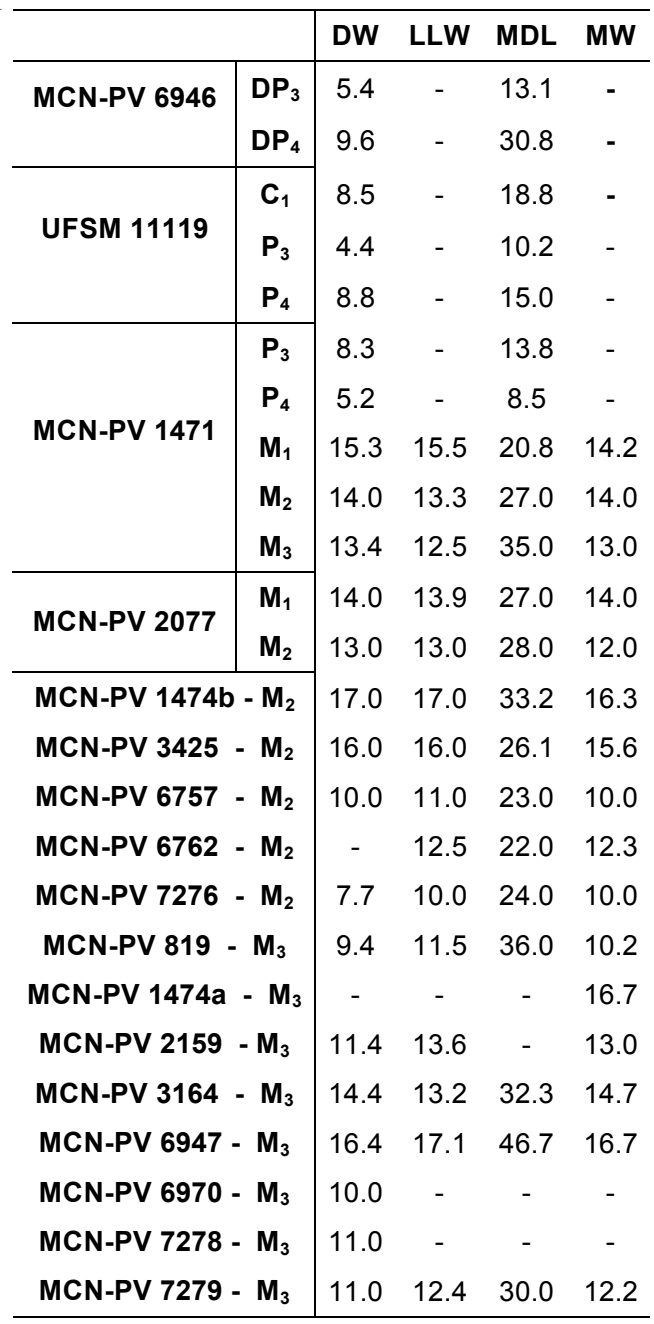

fourth sacral vertebra (S4). The neural spines are low and well separated, but united by a very low sacral sagital crest. In S3-S4 the neural spines are bifid (in S1-S2 are lacking). The dorsal sacral foramens are ovoid. The intervertebral foramens are oval shaped. In the dorsal face, the lateral sacral crests are low and they extend from the limit of S1 to approximately the half of S4. The prezygapophysis of S1 is very concave and turned medially. There were no sacral vertebrae of $H$. paradoxa in the collections for comparison. However, MCNPV 7927 is clearly larger than some specimens of P. major (MCL 6669, 6670) and $P$. weddelli. Due to this and for the same provenance of the cranial and postcranial material described bellow, this specimen was attributed to H. paradoxa.

\section{Fore Limb}

Humerus. In the best preserved specimen (MCN-PV 1973; Figure 6A), the distal condyle is wide and semicilindric, with two trochleae. The deepest one (middle area of the condyle) divides the condyle in two portions. The medial portion is slightly more distally pronounced, with larger anteroposterior and lateromedial diameters and a more rounded shape than the lateral one. This, more square shaped is the second troclea, 
A

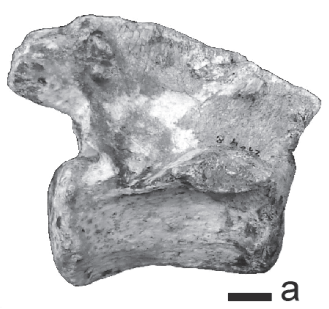

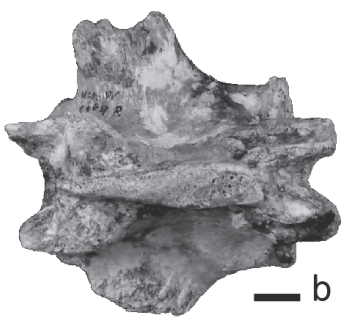
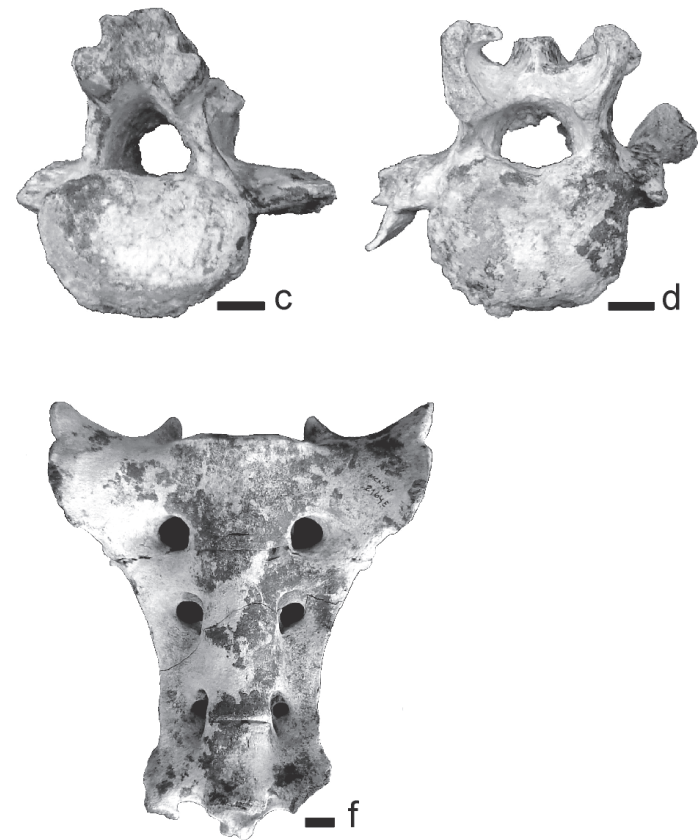

Figure 5. Hemiauchenia paradoxa: A, MCN-PV 2164, incomplete lumbar vertebrae in right lateral (a), dorsal (b), caudal (c) and cranial (d) views; B, MCN-PV 7927, sacrum in dorsal (e) and ventral (f) views. Scale bars $=1 \mathrm{~cm}$.

which is limited by two low, rounded crests, separated by a very shallow groove. Both medial and lateral portions articulate with the radius. The ulna only articulates with the humerus in a very little posterior area. This posterior ulnar facet is slightly concave and continuous with the larger trochlea. Entepicondyle and ectepicondyle are discreet structures, just with lower crests. In some specimens, can be observed the lateral supracondylar crest, which extends proximally, starting from the ectepicondyle. In the posterior surface, the condylar crests, which limit the olecranon fossa, are long, thick, and anteriorly projected, almost until the distal limit of the condyle. The lateral crest is thicker and the medial is the longest, and proximally, they are united in an "inverted V". The olecranon fossa is very deep, but "pseudocoronoid" fossa not so deep.

Radius-ulna. These bones are fused (Figure 6B), resulting in a complex long bone. The ulna is reduced to the olecranon process and a slender distal portion that extends along the posterolateral margin of the radius. The olecranon is high and long, but flat lateromedially. The axis of the olecranon is in line with the anconeal process and with the "pseudocoronoid" process. The semilunar notch is formed by the ulna just proximally, being the distal half formed by the proximal portion of the radius, which is very wide. The anconeal process and the articular facet for the posterior portion of the humeral condyle are formed only by the ulnar portion of the complex bone. Opposite to the anconeal process, there is in this portion of the radius, a process similar to the coronoid process of the ulna of other mammals, here called "pseudocoronoid" process, articulating to the coronoid fossa of the humerus, in its turn here called "pseudocoronoid" fossa for the same reason. At the semilunar notch one can't distinguish the limit between radius and ulna.
This extensive radial surface for the humeral condyle presents two continuous facets, separated from each other by the "pseudocoronoid" process. Both facets are concave, the lateral is semilunar, being separated from the anconeal process facet by a slight ligamental notch. The medial facet extends over the whole surface, corresponding to the notch, on the median crest of the notch and is continuous with the facet of the anconeal process. The distal end is formed by the radius, except perhaps, for a small posterolateral styloid ulnar process. This end is lateromedially wide, with two well marked crests that individualize three tendinous grooves (mediolateral direction): (i) long digital adductor; (ii) radial carpal extensor and (iii) common digital extensor. At this end, there are three articular facets: a lateral one, convex (semicilindric), posterodistally projected, for the pyramidal bone; a middle one, smaller and concave, for the lunar bone; and a medial, wider, for the scaphoid bone.

Carpal bones. The specimens MCN 2258 a-f(Figure 6C) were collected associated and so probably belong to a same individual, also because the bones articulate and form an almost complete carpus, just lacking the lunar.

The scaphoid (MCN-PV 2258b) is thick dorsopalmarly and narrow lateromedially. Proximally it is articulated with the radius by three facets: a dorsal one, small, convex and wider; another one, palmar to the first, concave dorsopalmarly, bigger and deeper laterally; the third, palmar to the others, is small, remarkably convex, and wider than high, with a rounded crest at the middle portion. The distal surface has two facets: the dorsal one is flat and extends over approximately half of the bone, for articulation with the magnum; and the palmar one, in the medial half of the bone, is very concave, rounded, and higher than wide, for the trapezoid. The lateral half of this surface presents a ligamental depression, and the facets 
A

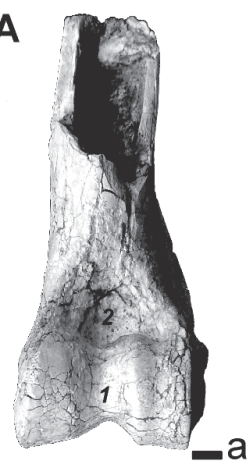

D

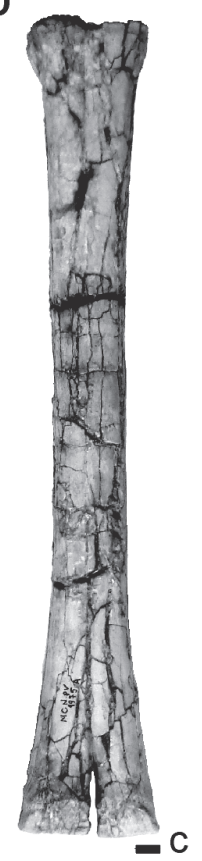

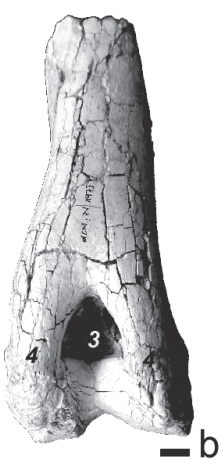

\section{B}

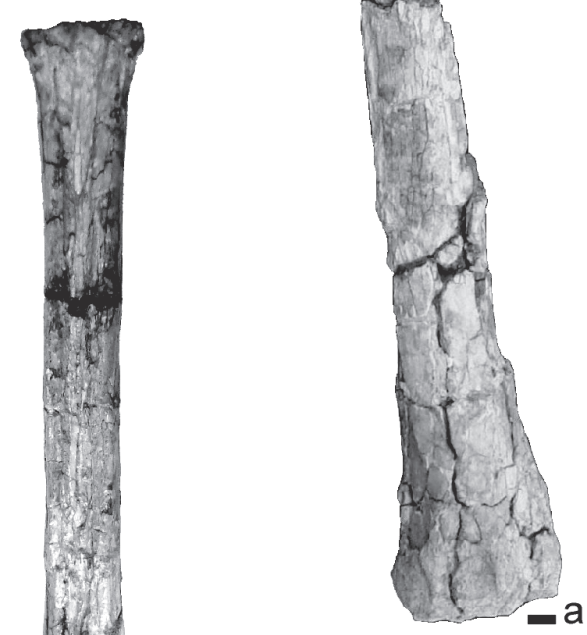

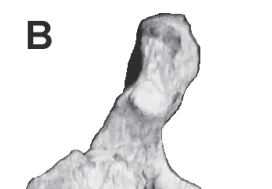
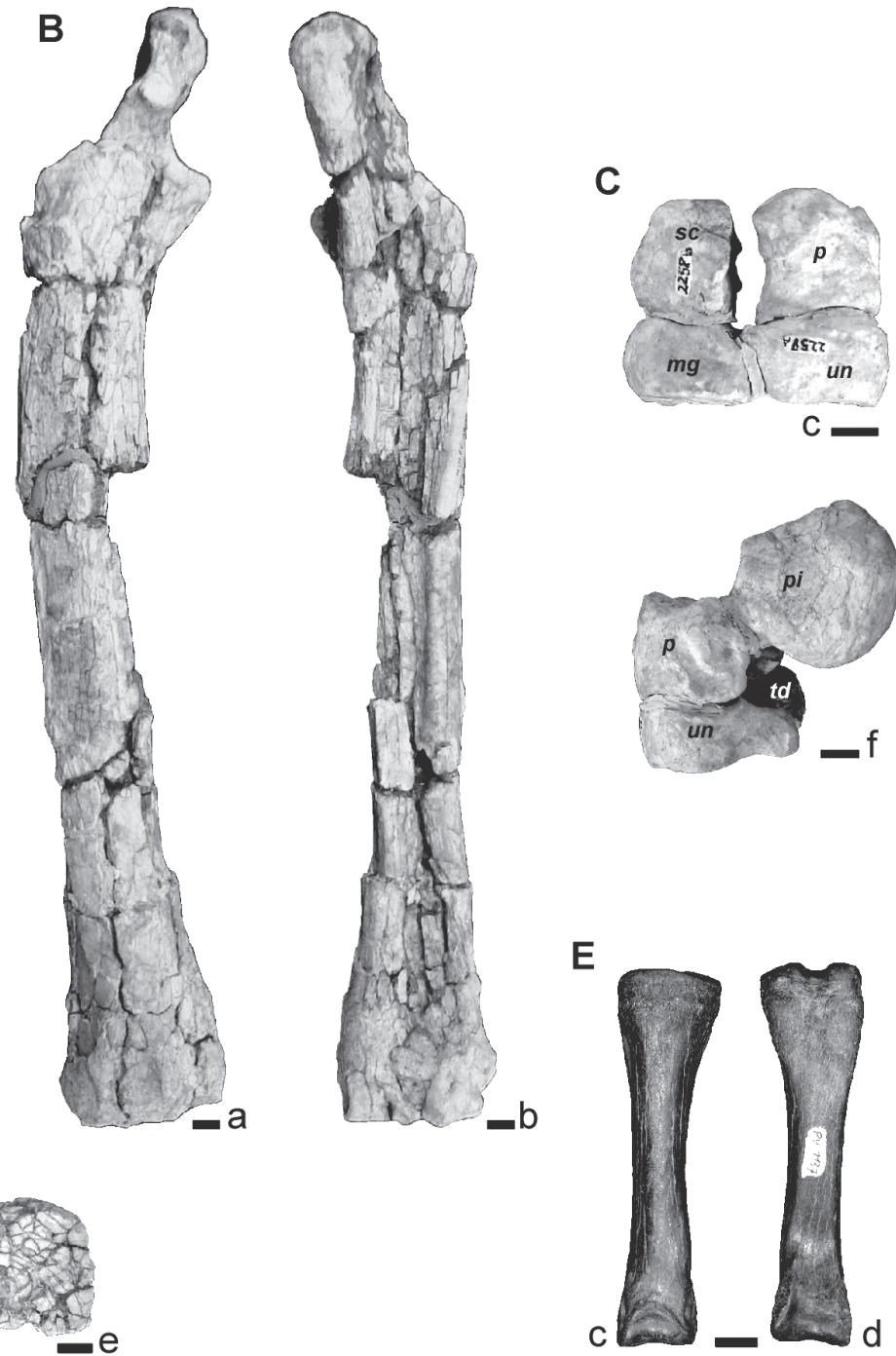

C
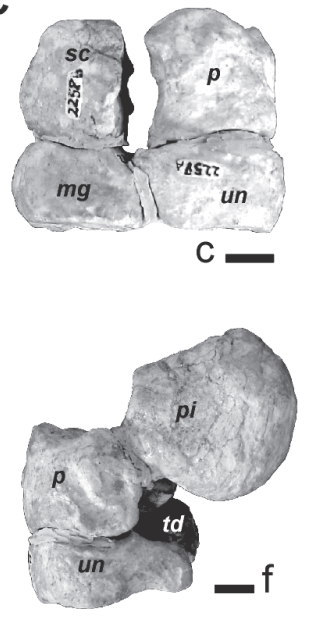

Figure 6. Hemiauchenia paradoxa. A, MCN-PV 1973, distal end of left humerus: 1, condyle; 2, "pseudocoronoid" fossa; 3, olecranon fossa; 4, condylian crests; B, MCN-PV 1975b, left radius-ulna; C, MCN-PV 2258, incomplete left carpus: sc, scaphoid; $p$, pyramidal; pi, pisiform; un, unciform; mg, magnum; $t$, trapezoid; D, MCN-PV 1975a, left metacarpals; E, MCN-PV 1137, right proximal phalanx of the manus. In anterior (a), posterior (b), dorsal (c), palmar (d), proximal axial (e), lateral (f) views. Scale bars $=1 \mathrm{~cm}$.

are limited by a lower crest. The lateral surface articulates with the lunar through three small facets: two dorsal ones, wider than high and flat, and a third palmar facet, slightly concave, oval shaped distolaterally. These three facets are separated by a ligamental depression. The dorsal, medial and palmar surfaces are rugous and slightly convex, and the medial one presents a small tubercle.

The pyramidal (MCN-PV 2258d, 7273) has a form similar to the scaphoid, with three proximal facets: the dorsomedial one is small, semilunar and slightly convex; palmar to this, there is a great facet, remarkably concave in the two lateral thirds and just slightly concave in the medial third. These two facets are separate by a low and rounded crest, without a prominent margin. A third palmar facet is tilted, for palmar articulation with the pisiform. In the distal face there is just a great semilunar facet for the unciform, dorsally convex and concave on the palmar side, which is medially tilted. The medial face is articulated with the lunar through two facets, a proximal one, convex, that extends in the palmar direction from the dorsal surface to the proximal facet for the pisiform, being dorsally convex and palmarly concave. The distal facet lacks its dorsal portion, and is separated from the palmar portion by a rounded crest. The proximal and distal facets are separated by a ligamental depression. The palmar and lateral faces are continuous, convex and rugose. The dorsal face is subdivided by a delicate crest in a medial concave portion and a lateral convex one, which continues for the lateral surface of the bone.

The pisiform (MCN-PV 2258e, 7047) is thick dorsopalmarly and slender lateromedially. Its free palmar end is convex, thick and rugose. This portion is separated from the articular one by a robust neck. In the articular portion there is a facet for the pyramidal, flat and distally inclined, which is smaller than the other radial facet, that is concave and dorsally returned. 
Table 4. Measurements ( $\mathrm{mm}$ ) of lumbar vertebrae of $H$. paradoxa. Abbreviations: $\mathrm{HCaF}$, height of caudal face of vertebral body; $\mathrm{HCrF}$, height of cranial face of vertebral body; HNA, height in the medium portion of neural arch; LVB, length of vertebral body in the medium portion of the neural face; TDca, transversal diameter of caudal face of vertebral body; TDcr, transversal diameter of cranial face of vertebral body; TDNA, transversal diameter in the medium portion of neural arch.

\begin{tabular}{c|ccccccc}
\hline & HCaF & HCrF & HNA & LVB & TDca & TDcr & TDNA \\
\hline $\begin{array}{c}\text { MCN-PV } \\
\mathbf{2 1 6 4 a}\end{array}$ & 28.8 & 26.0 & 16.7 & 55.6 & 43.7 & 36.9 & 18.1 \\
$\begin{array}{c}\text { MCN-PV } \\
\mathbf{2 1 6 4 b}\end{array}$ & 30.7 & 30.7 & 16.7 & 59.6 & 45.0 & 39.5 & 19.4 \\
$\begin{array}{c}\text { MCN-PV } \\
\mathbf{2 1 6 4 c}\end{array}$ & 29.4 & 33.2 & 17.0 & 57.4 & 41.1 & 41.9 & 19.2 \\
$\begin{array}{c}\text { MCN-PV } \\
\text { 2164d }\end{array}$ & 28.7 & 33.0 & 19.0 & 57.0 & 40.9 & 41.0 & 26.0 \\
\hline
\end{tabular}

Table 5. Measurements ( $\mathrm{mm}$ ) of humerus of Hemiauchenia paradoxa. Abbreviations: HOF, height of olecranon fossa; TDE, anteroposterior thickness of distal end; VDC, vertical diameter of condyle at the level of medial portion; WC, lateromedial width of condyle; WDE, width of the distal end; WOF, width of the olecranon fossa.

\begin{tabular}{l|cccccc}
\hline & HOF & TDE & VDC & WC & WDE & WOF \\
\hline MCN-PV 1973 & 23.5 & 61.0 & 37.8 & 68.4 & 65.6 & 20.0 \\
MCN-PV 2088 & 26.0 & 71.0 & 49.6 & 61.3 & 73.2 & 20.3 \\
MCN-PV 3334 & 22.9 & 55.0 & - & - & - & - \\
MCN-PV 3427 & 22.5 & 61.0 & 39.3 & - & 61.5 & 19.0 \\
\hline
\end{tabular}

Table 6. Measurements $(\mathrm{mm})$ of radius-ulna of $H$. paradoxa. Abbreviations: HSC, height of sigmoid cavity; TDAS, thickness of distal articular surface; TDE, thickness of distal end; TL, total length; TO, thickness of olecranon at anconeal process; TRH, anteroposterior thickness of radius "head"; WAP, width of anconeal process; WDAS, width of distal articular surface; WDE, width of distal end; WOT, lateromedial width of olecranon top; WPE, width of proximal end of radius.

\begin{tabular}{c|ccccccccccc}
\hline & HSC & TDAS TDE & TL & TO & TRH WAP WDAS WDE WOT WPE \\
\hline $\begin{array}{c}\text { MCN-PV } \\
\text { 1975b }\end{array}$ & 31.0 & 37.6 & 47.9 & 477.0 & 65.0 & 42.0 & 18.5 & 57.2 & 66.1 & 27.1 & 65.6 \\
$\begin{array}{c}\text { MCN-PV } \\
\begin{array}{c}\mathbf{2 0 8 2 b} \\
\text { MCN-PV }\end{array}\end{array}$ & - & 33.4 & 38.3 & - & - & - & - & 51.6 & 60.7 & - & - \\
$\begin{array}{c}\mathbf{3 3 5 9} \\
\text { MCN-PV }\end{array}$ & - & 37.5 & 39.0 & - & - & - & - & - & - & - & - \\
$\mathbf{6 5 7 5}$ & 26.2 & - & - & - & 51.0 & 33.0 & 17.0 & - & - & 20.0 & 52.7 \\
$\begin{array}{l}\text { UFSM } \\
\mathbf{1 1 3 2 5}\end{array}$ & - & 39.0 & 51.2 & - & - & - & - & 54.4 & 68.0 & - & - \\
\hline
\end{tabular}

These two facets are separated by a round and low crest. In the medial face there is a concavity that contributes in the lateral wall of the tunnel of the carpus. In the lateral face (convex) there is a tendinous groove.

The magnum (MCN-PV 2258c) is thin and presents a triangular proximal outline. The proximal surface bears a medial facet, concave and rounded, which occupies the dorsal portion, articulating with the scaphoid bone. In the lateral surface, the facet for the lunar extends from the dorsal portion into the posterolateral process, is high and slightly tilted proximally. These two facets are separated by a low crest that extends into the posterolateral process. The other facets of the lateral surface, for the unciform and lunar bones, were not distinguished due to the bad preservation. The distal surface articulates with the metacarpal III through a triangular, flat and wide facet. In the medial portion, a small part of the facet is turned medially. The medial surface is rugose, convex and continuous with the dorsal surface. The plantar surface is medially tilted, but not distinguishable from the facets for the trapezoid bone.

The trapezoid (MCN-PV 2258f) is a small and irregular bone. The proximal surface is convex and rounded, extending into the palmar surface for articulation with the scaphoid bone. The distal surface is flat with only one rounded facet, for articulation with the metacarpal III. The dorsal and lateral surfaces are continuous and present indistinct facets for the magnum due to poor preservation. The lateral surface is rugose and flat.

The unciform (MCN-PV 2258a) is high and thin, with a well-developed palmar unciform process (about $50 \%$ of the body). In the proximal surface, there is a wide triangular facet for the pyramidal, slightly convex in its lateral portion and concave in the medial one. In the anteromedial portion, there is a small facet for the lunar. These two facets are separated by a low crest. The distal surface presents a wide facet for the metacarpal IV, slightly concave and with triangular outline, not extending into the unciform process. The lateral and anterior surfaces are continuous, convex and rugose. In the medial surface, the facets for the magnum bone are not distinct, due to the bad preservation.

Metacarpals. The metacarpals III and IV are fused to each other ("canon bone") except at the distal end (Figure 6D). The proximal end is wide lateromedially and thin, with three articular facets. The lateral one, for the unciform bone, is larger, with an oval outline, extending from the dorsal to the palmar margin, being prolonged inward medial and dorsally to the limit of the medial facet. Medially, there are two facets: a small one, flat and rounded outline in the palmar portion, for the trapezoid and another for the magnum, in the dorsal portion, dorsomedially flat and concave in its palmar portion. This is more proximally projected than the lateral facet. The limit between these medial facets is irregular, separated by a low crest. In the middle portion of this surface there is a small and deep groove. At midline of the dorsal surface of the entire shaft of the bone there is a shallow groove, except distally, where the metacarpal condyles are independent each other. Correspondingly, at the midline of the palmar face there is a very wide and deep groove, along the whole extension of the bone, except in the distal fourth. Here, there are two condyles, each one with a typical central keel in the palmar face. The dorsal, distal and palmar faces are continuous and convex. The lateral condyle projects more distally and is slightly narrower than the medial one.

Phalanx. The proximal phalanx (MCN-PV 1137; Figure 6E) bears the proximal facet rounded and flat, and slightly concave. The proximal areas of muscular fixation in the palmar 


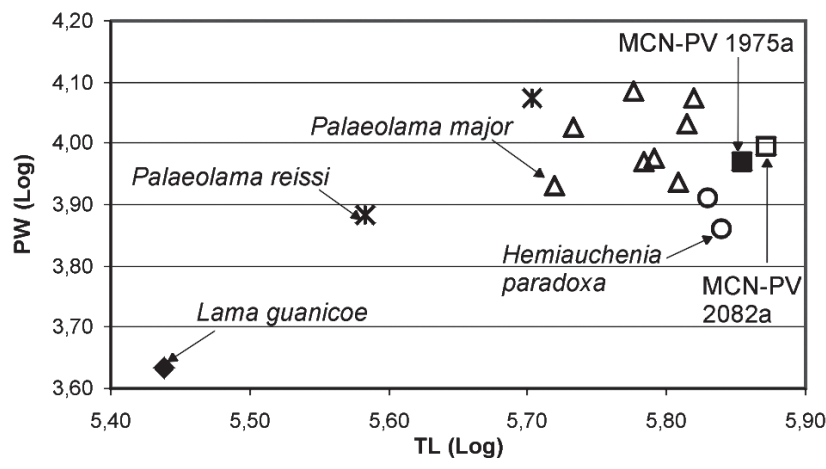

Figure 7. Graphic comparing the total length (TL) vs. proximal width (PW) of metacarpals of Hemiauchenia paradoxa (MCN-PV 1975a, 2082a; MLP 9-474, 9-482, Cabrera, 1935), Palaeolama major (MCL 1556, 1557, 5597, 5598, 6839, 6840, 6842, 6847; Cartelle, 1992), Palaeolama reissi (Hoffstetter, 1952) and Lama guanicoe (MCN-M 34/92, extant specimen).

surface extend until half the body of the bone. The transverse section is rounded. The distal end presents only one articular facet, extending dorsally. Ventrally, there is a small trochlea, with rounded condyles, the lateral larger than the medial one.

Some fore limb specimens from RS were previously attributed to Palaeolama major (Scherer et al., 2006), following the hypothesis of Cartelle (1992, 1999), which considered one species in Brazil and Argentina. Comparisons between the material of RS and material of these areas, showed no anatomical difference in the fore limb, but as mentioned in previous works (e.g. Webb, 1974), size can be a character to distinguish the postcranium of camelid species. There do exist some differences in the proportion of the fore limb of $H$. paradoxa (pampean area) and P. major (Brazil intertropical), mainly in the humerus, metacarpals (Figure 7) and phalanx, which are more slender in the first species. However, it is important to consider that the RS specimens preserved by carbonate are expanded, which makes them appear near in size to P. major.

\section{Hind Limb}

Femur. The better preserved distal portion of femur (MCNPV 3309; Figure 8A) is slightly thicker than wide. The condyles are asymmetric, the lateral bigger than the medial condyle. While the axis of the lateral condyle is vertical, the medial is medially inclined. There are two fossas in the lateral condyle: the largest one (origin of the digital extensor longus muscle) is in the angle between the condyle and the patelar facet, and the other one (origin of the popliteal muscle), is in the lateral margin of the condyle, marginating distally the lateral epicondyle. The proximal margin of the medial condyle is separated from the popliteal surface by a traverse groove, while the lateral condyle is continuous almost imperceptibly with the popliteal surface. The medial margin of the lateral condyle is more concave than the lateral margin of the medial condyle. Distally, the facets of femoral condyles are continuous with the patellar facet, which is very high and concave. The lateral margin of the facet is more prominent
Table 7. Measurements $(\mathrm{mm})$ of carpal bones of $H$. paradoxa. Abbreviations: L, proximodistal length; T, dorsopalmar thickness; W, lateromedial width.

\begin{tabular}{c|ccc}
\hline & L & T & W \\
\hline Scaphoid (MCN-PV 2258b) & 24.8 & 36.9 & 22.0 \\
Pyramidal (MCN-PV 2258d) & 25.2 & 32.5 & 18.0 \\
Pisiform (MCN-PV 2258e) & 38.0 & 42.3 & 20.4 \\
Trapezoid (MCN-PV 2258f) & 17.3 & 16.7 & 17.3 \\
Magnum (MCN-PV 2258c) & 15.80 & 27.7 & 25.4 \\
Unciform (MCN-PV 2258a) & 17.2 & 39.5 & 25.7 \\
Pyramidal (MCN-PV 7273) & 25.0 & 30.0 & 18.5 \\
Pisiform (MCN-PV 7047) & 31.7 & 34.0 & 16.0 \\
\hline
\end{tabular}

Table 8. Measurements $(\mathrm{mm})$ of metacarpals of $H$. paradoxa. Abbreviations: TL, total length; TPE, dorsopalmar thickness of proximal end; WDE, lateromedial width of distal end; WPE, width of proximal end.

\begin{tabular}{c|cccc}
\hline & TL & TPE & WDE & WPE \\
\hline MCN-PV 1975a & 348.7 & 40.3 & 61.4 & 53.0 \\
MCN-PV 2082a & 354.7 & 36.3 & 65.1 & 54.3 \\
MCN-PV 3278 & - & 34.1 & - & 45.7 \\
MCN-PV 6579 & - & 32.3 & - & 47.2 \\
\hline
\end{tabular}

Table 9. Measurements $(\mathrm{mm})$ of proximal phalanges of the manus of $H$. paradoxa. Abbreviations: DW, distal lateromedial width; PT, proximal thickness; PW, proximal width; TL, total length; TLC, dorsopalmar thickness of lateral condyle; TMC, thickness of medial condyle.

\begin{tabular}{c|cccccc}
\hline & DW & PT & PW & TL & TLC & TMC \\
\hline MCN-PV 2258g & 25.0 & - & - & - & 20.0 & 19.0 \\
MCN-PV 1137 & 21.0 & 26.4 & 26.0 & 100.0 & 20.50 & 17.50 \\
\hline
\end{tabular}

and extends slightly more proximally than the medial one. The popliteal fossa is deep. The intercondylar fossa is distally narrow and proximally wide. The medial epicondyle is small and continuous with the transverse groove that borders proximally the condyle.

Tibia. The proximal surface of tibia (MCN-PV 5662) has an equilateral triangle shape. The lateral facet is trapeziumshaped, and the medial is oval-shaped (larger anteroposterior diameter). Both facets are anteroposteriorly convex, but the lateral one is slightly concave near its lateral margin. The lateral tubercle is relatively low and rounded, whereas the medial is short, but high. The crest for the crossed ligaments is very delicate, and unites obliquely the middle portions of the tubercles. It was not possible to determine if the proximal portion of the fibula was fused or not to the lateral condyle. The groove between the proximal facets is wide, deep, and limits anteriorly the popliteal notch. The tibial tuberosity is ovoid, with an area similar to that of the femoral condyle facets. It is separated from the lateral facet by the deep tendinous groove ("sulcus muscularis", for the tendons of 
A

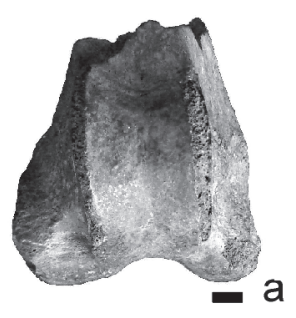

C
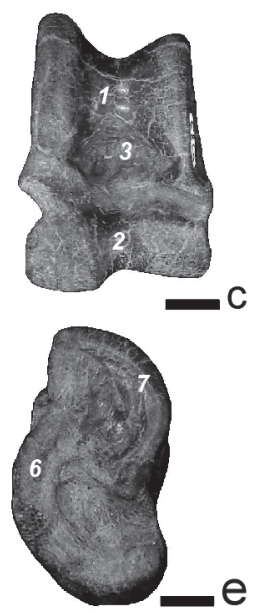

D

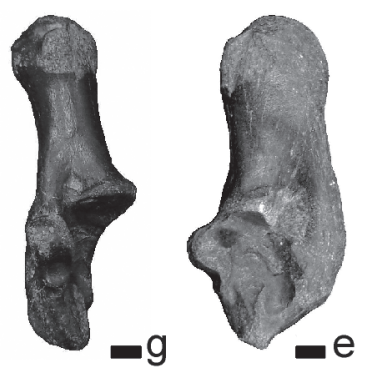

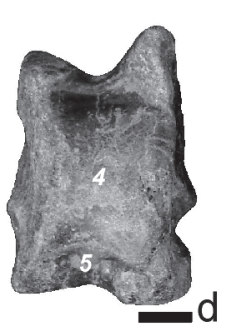
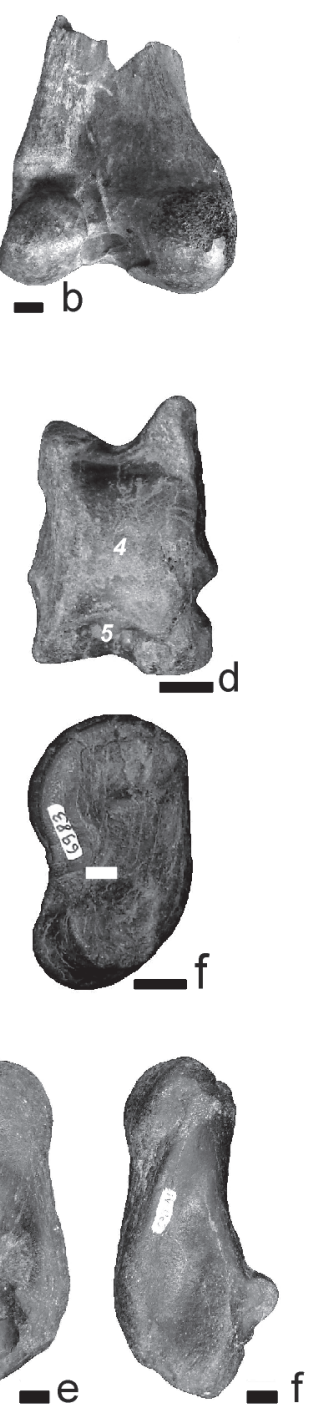

B
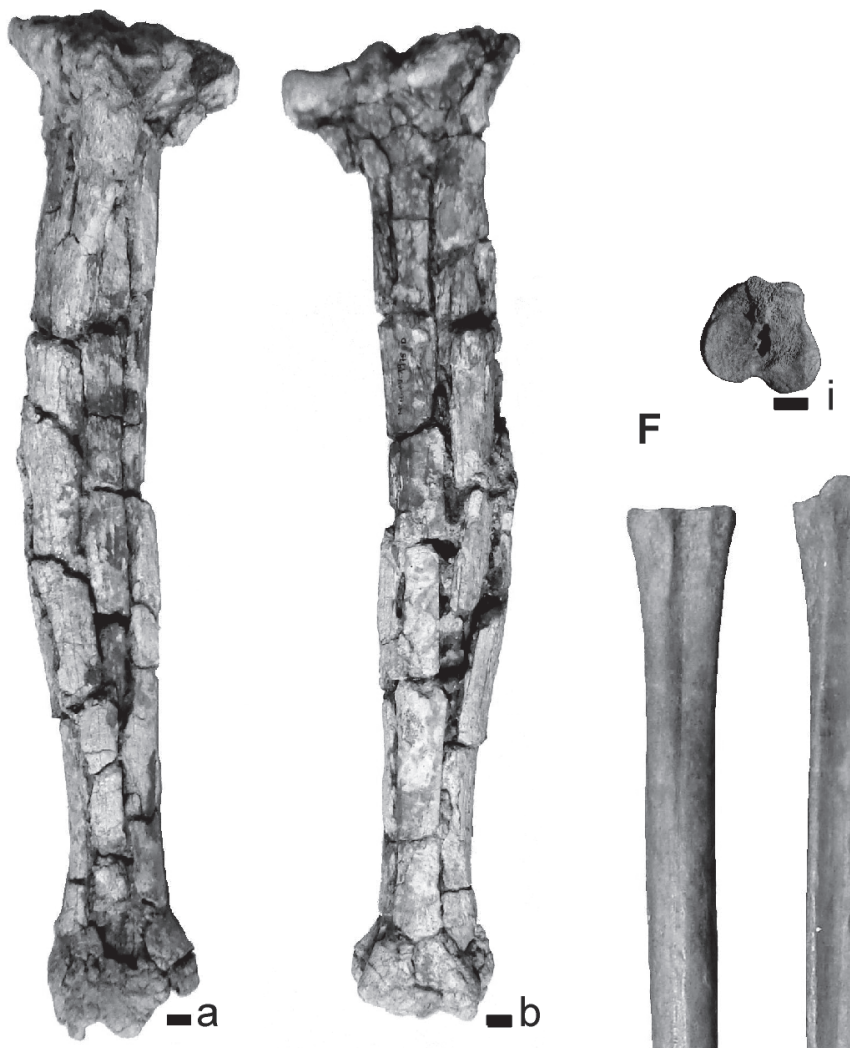

E
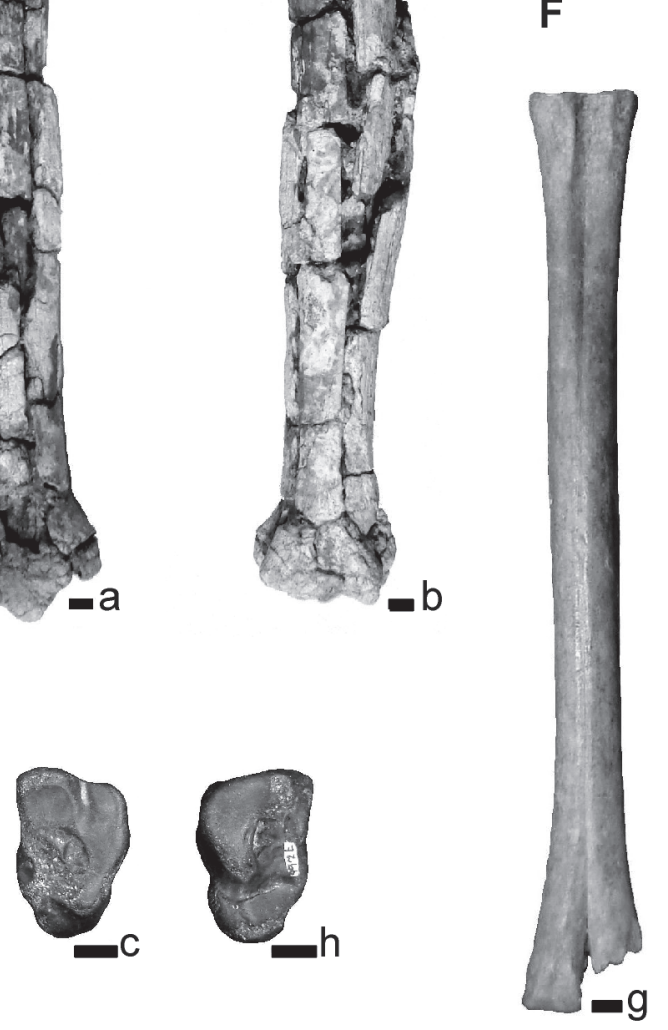

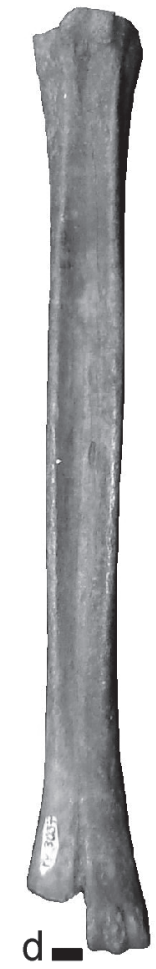

Figure 8. Hemiauchenia paradoxa. A, MCN-PV 3309, distal end of right femur; B, MCN-PV 1975d, left tibia; C, MCN-PV 6983, right astragalus: 1, proximal trochlea; 2, distal trochlea; 3, neck basis fossa; 4, sustentacular facet; 5 , subsustentacular fossa; 6 , parasustentacular facet; 7, maleolar facet); D, MCN-PV1163, right calcaneum; E, MCN-PV 7266, right cuboid; F, MCN-PV 3037, incomplete left metatarsus. In anterior (a), posterior (b), proximal (c), plantar (d), medial (e), lateral (f), dorsal (g), distal (h) and axial proximal (i) views. Scale bars $=1 \mathrm{~cm}$.

the digital extensor longus muscle, and anterior fibular muscle; Sisson \& Grossman, 1963). This tibial tuberosity is relatively narrow lateromedially, separating the anterolateral and anteromedial surfaces of the shaft of the bone. Distally (MCN-PV 1975d; Figure 8B), the crest tilts medially and towards the anteromedial surface, reduces progressively, becoming the rounded medial margin of the bone in the distal third, in direction to the malleolus. With the medial tilt of the tibial crest, the anterolateral surface becomes less tilted laterally, so that near the distal end it turns anterior. The lateral margin of the bone is thin in the proximal two thirds, and becomes thicker distally, towards the fibular groove. The posterior surface is concave in the proximal third, then becoming convex distally.

The tibial distal surface (MCN-PV 1975d) is rectangular, with the medial half slightly larger. In the astragalar notch, the facets for the proximal trochlea are very deep, oval, almost parallel with anteroposterior diameter largest. They are separated by a thick and rounded crest, wider than the facets themselves. This crest extends between two processes located at the anterior and posterior margins of the astragalar notch. The anterior, triangular and more prominent process is the more distally projected tibial structure, whereas the posterior process is smaller and rounded. The medial malleolus is very prominent and forms the anterolateral wall of the astragalar notch, which is slightly inclined in the direction of the facet. Two small crests extend between the medial malleolus and the anterior/posterior processes, forming the limits of the medial facet. Similar crests extend from the triangular processes towards the fibular groove, forming the margins corresponding to the lateral facet. In the lateral margin there is a fibular groove, very long and vertical 
Table 10. Measurements $(\mathrm{mm})$ of femora of $H$. paradoxa Abbreviations: DWT, distal width of trochlea; PWT, proximal width of trochlea; TDE, thickness (anteroposterior) of distal end; WDE, width (lateromedial) of distal end; WIF, width of intercondylar fossa.

\begin{tabular}{c|ccccc}
\hline & DWT & PWT & TDE & WDE & WIF \\
\hline MCN-PV 3309 & 31.6 & 38.4 & 81.4 & 85.3 & 26.4 \\
MCN-PV 1975c & 31.0 & - & 86.0 & 81.7 & 22.6 \\
\hline
\end{tabular}

Table 11. Measurements $(\mathrm{mm})$ of tibiae of $H$. paradoxa. Abbreviations: DTS, distance between tubercles of spine; LC, length of crest; TDAS, thickness of distal articular surface; TDE, anteroposterior thickness of distal end; TL, total length; TPE, thickness of proximal end; WDAS, width of distal articular surface; WDE, lateromedial width of distal end; WPE, width of proximal end.

\begin{tabular}{|c|c|c|c|c|c|c|c|c|c|}
\hline & DTS & LC & TDAS & STDE & $\mathrm{TL}$ & TPE & WDAS & SWDE & EWPE \\
\hline $\begin{array}{c}\text { MCN-PV } \\
1975 d\end{array}$ & 16.11 & 109.7 & 35.0 & 43.4 & 400.0 & 090.0 & 34.5 & 59.5 & 92.4 \\
\hline $\begin{array}{c}\text { MCN-PV } \\
3233\end{array}$ & - & - & 27.4 & 32.4 & 400.0 & 0 & 33.3 & 50.1 & 67.6 \\
\hline $\begin{array}{c}\text { MCN-PV } \\
3234\end{array}$ & - & - & - & -3 & 379.1 & $1-$ & - & & 67.4 \\
\hline $\begin{array}{c}\text { MCN-PV } \\
5662\end{array}$ & 17.01 & 116.8 & - & - & - & 80.0 & - & - & 81.7 \\
\hline
\end{tabular}

(3-4 cm), deep, larger than $1 \mathrm{~cm}$, for articulation with the odontoid process of the fibular bone. Marginating anterior and posteriorly this groove, there are two small facets, distally directed, slightly concave and rounded, for articulation with the proximal portion of the fibula.

Astragalus. This is a rectangular bone (e. g. MCN-PV 6983; Figure 8C), with two trochleae: the proximal one, for the tibial notch, and the distal one for the navicular and cuboid bones. The proximal trochlea extends over must of the proximal surface of the bone. It presents two semicircular crests, almost parallel, very high and narrow, separated by a deep and very wide groove. Its articular surfaces are continuous from the crests over the groove, and over the lateral and medial surfaces of the bone. The lateral crest is higher and projected more proximally than the medial one, ending abruptly without reaching the plantar surface of the bone. The medial crest extends slightly more plantarly than the lateral one. The groove of the proximal trochlea ends in a deep oval/triangular fossa. There, when the foot is at maximum flexion, it articulates with the anterior process of the distal tibia. A thick, sinuous traverse crest limits distally this fossa, and unites the trochlear crests and condyles of the distal trochlea, forming two bridges, one delicate at the medial side, and a thick one at the lateral side.

The distal trochlea, differently from the proximal one, presents two low and very asymmetric condyles. Though, different from other trochleae, here the condyles are separated by a crest, and the groove adjacent is articulated as the medial condyle with the navicular bone. The deep and wide groove of the "medial condyle" extends to the subsustentacular fossa, in the plantar direction and towards the lateral margin of it, being separated from the sustentacular facet by only a narrow articular groove. The lateral condyle is narrower than the medial one, presents the facet for the
Table 12. Measurements $(\mathrm{mm})$ of astragali of $H$. paradoxa. Abbreviations: $L$, length from lateral proximal crest to lateral distal condyle; LTT, length of tibial trochlea; MW, maximum width; T, proximoplantar thickness; TN, thickness of the neck; TNT, thickness of navicular trochlea; WN, lateromedial width of the neck; WNT, width of navicular trochlea; WTT, width of tibial trochlea.

\begin{tabular}{|c|c|c|c|c|c|c|c|c|c|}
\hline & $\mathbf{L}$ & LTT & MW & $T$ & TN & TNT & WN & WNT & WTT \\
\hline $\begin{array}{c}\text { MCN-PV } \\
2181\end{array}$ & 63.3 & 36.3 & 43.0 & 32.7 & 30.0 & 21.2 & 39.2 & 39.3 & 30.0 \\
\hline $\begin{array}{c}\text { MCN-PV } \\
6980\end{array}$ & 53.9 & 32.2 & 32.5 & 29.0 & 25.5 & 15.9 & 31.6 & 31.3 & 18.5 \\
\hline $\begin{array}{c}\text { MCN-PV } \\
6982\end{array}$ & 50.0 & 30.0 & 30.7 & 27.9 & 24.8 & 17.8 & 29.9 & 31.2 & 20.4 \\
\hline $\begin{array}{c}\text { MCN-PV } \\
6983\end{array}$ & 55.3 & 32.6 & 37.0 & 33.0 & 26.9 & 22.9 & 32.8 & 35.8 & 21.0 \\
\hline $\begin{array}{c}\text { MCN-PV } \\
6984\end{array}$ & 54.8 & 32.0 & 37.0 & 29.4 & 26.3 & 19.8 & 33.1 & 34.5 & 22.1 \\
\hline $\begin{array}{c}\text { MCN-PV } \\
7012\end{array}$ & 51.6 & 31.2 & 32.0 & 26.7 & 24.6 & 17.0 & 31.3 & 31.0 & 23.2 \\
\hline $\begin{array}{c}\text { MCN-PV } \\
7013\end{array}$ & 50.7 & 30.7 & 33.2 & 30.2 & 26.6 & 20.0 & 32.2 & 32.7 & 23.3 \\
\hline $\begin{array}{c}\text { MCN-PV } \\
7014\end{array}$ & 50.7 & 29.9 & 35.9 & 25.6 & 25.2 & 16.5 & 34.2 & 35.4 & 24.5 \\
\hline $\begin{array}{c}\text { MCN-PV } \\
7015\end{array}$ & 52.1 & 33.0 & 35.3 & 31.5 & 26.7 & 21.2 & 32.1 & 30.8 & 26.4 \\
\hline $\begin{array}{c}\text { MCN-PV } \\
7016\end{array}$ & 51.0 & 30.2 & 32.4 & 26.0 & 25.0 & 16.4 & 30.9 & 30.0 & 23.0 \\
\hline $\begin{array}{c}\text { MCN-PV } \\
7017\end{array}$ & 51.3 & 27.1 & 32.5 & 24.7 & 24.2 & 16.7 & 30.8 & 32.7 & 24.7 \\
\hline $\begin{array}{c}\text { MCN-PV } \\
7018\end{array}$ & 51.7 & 28.7 & 33.2 & 28.0 & 27.0 & 16.4 & 31.8 & 31.5 & 24.0 \\
\hline $\begin{array}{c}\text { MCN-PV } \\
7019\end{array}$ & 54.5 & 31.9 & 34.3 & 25.0 & 24.5 & 13.6 & 32.4 & 32.2 & 24.4 \\
\hline $\begin{array}{c}\text { MCN-PV } \\
7020\end{array}$ & 49.3 & 29.6 & 31.0 & 24.4 & 23.0 & 15.3 & 30.0 & 29.3 & 21.3 \\
\hline $\begin{array}{c}\text { MCN-PV } \\
7021\end{array}$ & 51.2 & 29.8 & 35.0 & 27.5 & 24.7 & 19.1 & 32.2 & 35.3 & 25.0 \\
\hline $\begin{array}{c}\text { MCN-PV } \\
7268\end{array}$ & - & - & - & 29.0 & 25.0 & - & - & - & - \\
\hline $\begin{array}{c}\text { MCN-PV } \\
7269\end{array}$ & 37.0 & 20.5 & 24.0 & 18.0 & 18.0 & - & 23.0 & 23.0 & 22.0 \\
\hline $\begin{array}{c}\text { MCN-PV } \\
7270\end{array}$ & 34.0 & 19.0 & 22.0 & 17.0 & 15.0 & - & 20.0 & 21.0 & 20.0 \\
\hline $\begin{array}{c}\text { MCN-PV } \\
7271\end{array}$ & 46.0 & 25.0 & 26.0 & 23.6 & 21.0 & 15.0 & 26.0 & 27.0 & 24.6 \\
\hline $\begin{array}{c}\text { MCN-PV } \\
7272\end{array}$ & 46.0 & & 29.0 & 24.0 & 22.0 & - & 26.5 & 29.0 & 28.0 \\
\hline
\end{tabular}

cuboid bone, and extends towards the plantar surface of the bone, but its articular facet is not continuous with the sustentacular facet, since they are united just by an irregular crest.

The plantar surface is occupied by the wide sustentacular facet for the calcaneum and the subsustentacular fossa. The facet is remarkably convex proximodistally, and slightly concave lateromedially. Continuous to this, there are two small facets in the plantar portion of the crests of the proximal trochlea. That of the medial crest is semilunar, and laterally 


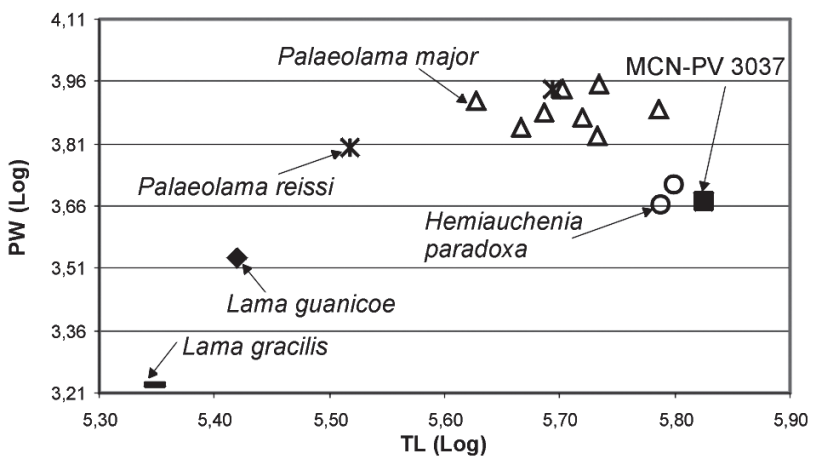

Figure 9. Graphic comparing the total length (TL) vs. proximal width (PW) of metatarsals of $H$. paradoxa (MCN-PV 3037; MLP 9101, 9-474, Cabrera, 1935); P. major (MCL 5396, 5397, 5399, 5400, 6881, 19054, 19057, 19061, Cartelle, 1992); P. reissi (Hoffstetter, 1952); L. guanicoe (MCN-M 34/123, extant specimen); and $L$. gracilis (MLP 71-XI-1-1).

oriented. The subsustentacular fossa is deep, oval-shaped, and articulates with the "sustentacular process" of the navicular bone, when the foot is in flexion. An oblique face, slightly rugose, unites the sustentacular facet to the medial face of the bone, in a proximodistal/ posteromedial orientation.

In the medial surface is the semilunar articular facet for the medial malleolus of the tibia, which is continuous with the medial crest of the proximal trochlea and extends between the plantar limit of the trochlea (proximally) and the medial process (distally). Distally, the medial surface of the medial condyle is rugose (ligamental) and depressed in the center. An oblique surface that is projected dorsally, starting from the medial margin of the sustentacular facet is located on the plantar side.

The lateral surface is more complex. The facet of the lateral crest of the proximal trochlea extends to the most dorsal portion of the lateral surface, which is articulated with the medial portion of the fibula. This facet is semilunar and extends between the plantar limit of the crest (proximally) and the lateral apophysis, which is larger than the process of the medial surface. In the plantar portion of the lateral surface, the oval parasustentacular facet for the calcaneum is the lateral extension of the sustentacular facet. These two facets are united for an articular prolongation of the parasustentacular facet, at the level of the lateral apophysis. Distally, an extension of the articular facet of the lateral condyle is a semilunar articular facet for the anterior portion of calcaneum. Between these facets, non-articulating areas are rugous and deeper for ligamental fixation.

Calcaneum. This bone is high, long, and narrow (e. g. MCNPV 1163; Figure 8D). The corpus calcanea, which ends in the tuberosity, bears a rectilinear dorsal margin, except distally near the "sustentacular process", where it is slightly concave and divides in two: a medial is thicker and forms the dorsal portion of the sustentacular facet for the astragalus; and a lateral one ends in the "fibular process", where articulates the fibula. The plantar margin of the bone is narrower than the dorsal one, and in its distal portion is remarkably convex, ascending toward a rugose surface, plantar to the cuboid facet.
Table 13. Measurements $(\mathrm{mm})$ of calcaneum of $H$. paradoxa. Abbreviations: LDM, length of dorsal margin; ML, maximum length; MT, maximum dorsoplantar thickness near to articular face; MW, maximum lateromedial width near to articular face; TT, thickness of tuberosity; WT, width of tuberosity.

\begin{tabular}{c|cccccc}
\hline & LDM & ML & MT & MW & TT & WT \\
\hline MCN-PV 1163 & 64.0 & 120.5 & 57.0 & 36.0 & 41.0 & 30.6 \\
MCN-PV 2079 & 64.0 & - & - & 32.2 & 32.3 & 27.7 \\
MCN-PV 6576 & 64.4 & 120.0 & 55.3 & 37.0 & 39.5 & - \\
\hline
\end{tabular}

The tuberosity is very prominent, oval in axial view, and with several smaller structures: rugose and convex dorsally ("serous bag" for the Achilles Tendon), a round tubercle plantar to this, and a groove for fixation of the Achilles Tendon. The whole tuberosity margin is marked by an irregular and prominent crest. The crest thickens forming the prominent plantar medial and lateral tubercles of the tuberosity.

The lateral surface of the bone presents a thick longitudinal crest, located plantar to the "fibular process" and extends distally towards the rugosity (plantar to the cuboid facet). This rugosity forms the distal margin of a longitudinal depression located in the center of the lateral surface. The medial surface of the corpus is similar to the lateral one, but is convex and continuous with the dorsal surface.

The anterior portion of the bone is wider and higher than the posterior one. This portion bears the distal head with the cuboid facet, the sustentaculum tali and the fibular process. The dorsal portion of the head is wider than the plantar one. The plantar portion presents a facet for the cuboid that is distal, semilunar, laterally convex and plantarly inclined. The dorsal portion of this facet is medially continued by the distal astragalar facet, which is prolonged proximodistally and remarkably concave, for articulation with the semilunar distal astragalar facet (near to the lateral condyle of the distal astragalar trochlea). Laterally is the complex facet for articulation with the fibula (distal remnant of the fibula). The facet has two different portions: a proximal, smaller one, remarkably concave, and a distal one, strongly convex that extends over the whole dorsal face of the "fibular process". Medial to the "fibular process", continues with the fibular facet, is the parasustentacular facet that is small, semicircular slightly convex, and articulates with the homonymous facet of the astragalus. In the distal surface of the sustentaculum tali locates the sustentacular facet, for the homonymous astragalar facet, which is distally directed, saddle-shaped, and dorsally forms the rounded margin of the sustentaculum. The medial portion of the sustentacular facet is broken in all specimens. As in the astragalus, the parasustentacular and sustentacular facets are continuous, forming nearly a right angle. Between the distal astragalar and the sustentacular facet there is a deep fossa.

Cuboid. Not well preserved (MCN-PV 7266; Figure 8E), it is a short bone with triangular proximal and distal surfaces. The thickness (dorsoplantar) and width (lateromedial) are similar 
( $\sim 41.5 \mathrm{~mm}$ ), about twice the length (proximodistal; $\sim 22.0 \mathrm{~mm}$ ), slightly larger in the lateral half. The proximal surface is better preserved in the dorsal half, where the lateral facet for the calcaneum is plantarly narrower. The medial facet, for the lateral condyle of the distal astragalar trochlea is concave. In the distal and medial surfaces of the bone there are facets for metatarsal IV. The largest one, near the dorsolateral angle of the distal surface, is semilunar and slightly concave in its central portion. Medial to this facet there is a rugose depression for an interosseus ligament, the rest of the distal surface being medially inclined. The second facet for metatarsal IV is low and wide, slightly medially oblique, and separated plantarly from the semilunar facet by a groove. In the limit between distal and medial surfaces, near the dorsodistal angle of the bone, there is the small, high, and narrow facet for the ectocuneiform. Below the middle point of the medial surface of the bone, there is a navicular facet, which is small, rounded and slightly proximally inclined. In the plantar end, there is a rounded process. The anterior and lateral surfaces are continuous, slightly convex and rugose. Metatarsals. As the metacarpals, the metatarsals III and IV are fused in a long bone ( $338.5 \mathrm{~mm}$ long), separated at the distal end (MCN-PV 3037; Figure 8F). The proximal end has a quadrangular outline, with a width of $39.4 \mathrm{~mm}$ and a thickness of $35.2 \mathrm{~mm}$. It presents three articular facets: two dorsal of semilunar shape, the lateral larger one for the cuboid bone, the medial one slightly smaller, for the entocuneiform. The plantar limit of these two facets is marked by a shallow concave facet. There is a proximal projection of the plantar surface, with facets for the ectomesocuneiform and cuboid, but that are not distinct from each other. Along the middle of the dorsal surface there is a shallow groove. In the plantar surface there is a very wide and deep groove, along the whole extension of the bone, except in the distal fourth. In the distal end, the lateral condyle is broken, corresponding to the distal end of metatarsal IV. In the medial condyle, there is keel at the center of the plantar surface. The dorsal, distal and plantar faces of the condyle are continuous and convex.

No significant morphologic differences were observed in the hind limb between P. major and H. paradoxa. Some specimens (e. g. MCN-PV 1975c,d; MCN-PV 2181) previously attributed to P. major (Scherer et al., 2006), following Cartelle (1999), show some differences in the proportions of the tibiae, astragalus and mainly in the metatarsals, and are clearly near to H. paradoxa, being more slender than in P. major (Figure 9). Although some bones (e. g. MCN-PV 1975d) also have similar dimensions to $P$. major, these specimens are much expanded due to preservation with carbonate.

\section{FINAL CONSIDERATIONS}

Comparing the dental and postcranial camelid materials of Rio Grande do Sul (RS) to those from Argentina, various characters emerge in the mandible proportions, morphology of the lingual lophs and labial lophids in the molar teeth, protostylid and parastylid size in the molars and proportions of the distal segments of limbs, that differ from P. major of the intertropical Brazil. On this basis the RS material is attributed to Hemiauchenia paradoxa, which is considered the only valid species for Uruguay and Argentina by most authors $(e$. g. Menegaz et al, 1989; Cione \& Tonni, 1995; 1999, 2005; Ubilla, 2004). Up to now no important morphologic differences in the postcranium of P. major and H. paradoxa was found, and since the sample of specimens of $H$. paradoxa studied was small, to test the hypothesis whether there is a real difference in such bone proportions, a larger sample is necessary, but in paleontological research is not always available. Because of these facts, the distinction between these two species is better supported by tooth characters, and the postcranial material is tentatively attributed to $H$. paradoxa.

The camelids of Rio Grande do Sul, pertaining to an area between the pampean and the intertropical areas, could present forms of both genera. Such material presently seems more similar to that of the Pampean area, but even the taxonomy here could be changed on the basis of new discoveries and revision of the systematics of the group, a very complex one mainly due to the great similarity in the skeletons of the South American camelids, and the existing diagnoses that are based on very variable characters.

Cartelle (1999) considered that $P$. major would be conspecific to the Argentina species, and that $P$. major could have originated in the south, and afterwards migrated to the north, where it lived in the intertropical area. In this study, it was observed that the intertropical species is not the same one that lived in the pampean area.

Many authors considered the camelids as good paleoenvironmental indicators (e. g. Tonni, 1985; Alberdi et al., 1989), because the living camelids are restricted to cold and dry regions. On basis of the presence of fossil camelids, it could be imputed a colder and dryer climate during the late Pleistocene in Rio Grande do Sul State. Most interesting perhaps is that this agree with the palynological data for this region (Behling et al., 2005).

\section{ACKNOWLEDGMENTS}

The authors thank to MCN/FZBRS and UFSM for the access to studied specimens; to M. Reguero (MLP) and A. Kramarz (MACN) for the permission to access the collections; to F. Abdala for many suggestions; to F. Buchmann and A. da Rosa (UFSM), for contributing to the geological studies; to L. Rota who collected many of the studied fossils; to Conselho Nacional de Desenvolvimento Científico e Tecnológico for finantial support (CSS).

\section{REFERENCES}

Alberdi, M. T.; Menegaz, A. N.; Prado, J. L. \& Tonni, E. P. 1989. La fauna local Quequén Salado Indio Rico (Pleistoceno Tardio) de la Província de Buenos Aires, Argentina. Aspectos paleoambientales y bioestratigráficos. Ameghiniana, 25(3): 225-23.

Behling, H.; Pillar, V. D. \& Bauermann, S. G. 2005. Late Quaternary 
grassland (Campos), gallery forest, fire and climate dynamics, studied by pollen, charcoal and multivariate analysis of the São Francisco de Assis core in western Rio Grande do Sul (southern Brazil). Review of Palaeobotany and Palynology, 133: 235-248.

Bergqvist, L.P. 1993. Jazimentos Pleistocênicos do Estado da Paraíba e seus Fósseis. Revista Nordestina de Biologia, 8(2):143-158.

Bombim, M. 1976. Modelo Paleoecológico Evolutivo para o Neoquaternário da Região da Campanha-Oeste do Rio Grande do Sul (Brasil). A Formação Touro Passo, seu conteúdo fossilífero e a pedogênese pós-deposicional. Comunicações do Museu de Ciências da PUCRS, 15:1-90.

Buchmann, F.S.C. 1994. Distribuição de fósseis pleistocênicos na zona costeira e plataforma continental interna no Rio Grande do Sul. Acta Geologica Leopoldensia, 17(39/1):355-364.

Buchmann, F.S.C. 2002. Bioclastos de organismos terrestres e marinhos na praia e plataforma interna do Rio Grande do Sul: natureza, distribuição, origem e significado geológico. Curso de Pós-Graduação em Geociências, Universidade Federal do Rio Grande do Sul, Tese de Doutorado, 108 p.

Cabrera, A. 1931. Sobre los camélidos fósiles y actuales de la América austral. Revista del Museo de La Plata, 33:89-117.

Cabrera, A. 1935. Sobre la osteologia de Palaeolama. Anales del Museo Argentino de Ciencias Naturales "Bernardino Rivadavia”, Paleontología: Vertebrados, 66:283-312.

Cartelle, C. 1992. Edentata e Megamamíferos Herbivoros extintos da Toca dos Ossos (Ourolândia, BA, Brasil). Universidade Federal de Minas Gerais, Tese de Doutorado, 301 p.

Cartelle, C. 1999. Pleistocene Mammals of the Cerrado and Caatinga of Brazil. In: J. F. Eisenberg \& K. H. Redford (eds.) Mammals of the Neotropics, The Central Neotropics, The University of Chicago Press, p. 27-46

Cartelle, C.; Brant, W. \& Pilo, L. B. A. 1989. Gruta do Túnel de Santana (BA): Morfogênese e Paleontologia. In: CONGRESSO BRASILEIRO DE PALEONTOLOGIA, 11, 1989. Anais, Curitiba, p. 593-606.

Cione, A. L. \& Tonni, E. P. 1995. Bioestratigrafía e cronología del Cenozóico Superior de la Región Pampeana. In: M. T. Alberdi; G. Leone \& E. P. Tonni (eds.) Evolución biológica y climática de la región Pampeana durante los últimos cinco millones de años. Un ensayo de correlación con el Mediterráneo occidental, CSIC, Monografías del Museo Nacional de Ciencias Naturales, p. 49-74.

Cione, A.L. \& Tonni, E. P. 1999. Biostratigraphy and chronological scale of upper-most Cenozoic in the Pampean Area, Argentina. In: J. Rabassa \& M. Salemme (eds.) Quaternary of South America and Antartic Peninsula, AA Balkema Publishers, p. 23-51.

Cione, A.L. \& Tonni, E. P. 2005. Bioestratigrafía basada em mamíferos del Cenozóico Superior de la Província de Buenos Aires, Argentina. In: R. E. Barrio; R. O. Etcheverry; M. F. Caballé \& E. Llambias (eds.) Geología y recursos Minerales de la Província de Buenos Aires, Quick Press, p. 183-200.

Cione, A. L.; Tonni, E. P.; Bond, M.; Carlini, A.; Pardiñas, U.F.J.; Scillato-Yané, G.; Verzi, D. \& Vucetich, M. G. 1999. Ocurrence charts of Pleistocene Mammals in the Pampean area, eastern Argentina. In: J. Rabassa \& M. Salemme (eds.) Quaternary of South America and Antartic Peninsula, AA Balkema Publishers, p. 53-59.

Da Rosa, A. A. S. 2003. Preliminary correlation of fluvial deposits at the extreme west of Rio Grande do Sul State, southern Brazil. In: LATINAMERICAN CONGRESS OF SEDIMENTOLOGY, 3, 2003. Abstracts, Belém, p. 243-245.
Góes, F. A. S.; Vieira, F. S.; Zucon, M. H.; Cartelle, C. \& Teodósio, C. 2002. Ocorrência de mamíferos pleistocênicos em Sergipe, Brasil. Arquivos do Museu Nacional, 60(3):199-206.

Guérin, C.; Souza, M.F. \& Vogel, M.A.C. 1990. A fauna Pleistocênica de São Raimundo Nonato (Piauí, Brasil), Implicações paleoecológicas. In: CONGRESSO BRASILEIRO DE GEOLOGIA, 36, 1990. Anais, Natal, p. 490-502

Hershkovitz, P. 1982. Neotropical deer (Cervidae), part I, Pudus, Genus Pudu Gray. Fieldiana, Zoology, 11:1-86.

Hoffstetter, R. 1952. Les mammiféres pléistocènes de la République de l'Equateur. Mémoires de la Société Géologique de France (Nouvelle série), 66:1-391.

Kotzian, C. B.; Simões M. G.; Da Rosa, A. A. S. \& Milder, S.E.S. 2005. AMS Radiocarbon dating of freshwater mollusk shells from the Touro Passo Formation (Pleistocene-Holocene), RS, Brazil. In: CONGRESSO BRASILEIRO DE PALEONTOLOGIA, 19, CONGRESSO LATINO-AMERICANO DE PALEONTOLOGIA, 6, 2005. CD Resumos, Aracaju.

Lopes, R. P.; Buchmann, F. S. C.; Caron, F. \& Itusarry, M. E. 2001. Tafonomia dos fósseis de vertebrados (Megafauna Extinta) encontrados nas barrancas do Arroio Chuí e linha de costa, Rio Grande do Sul, Brasil. Pesquisas em Geociências, 28(2):67-73.

López-Aranguren, D. J. 1930. Camélidos fósiles argentinos. Anales de la Sociedad Científica Argentina, 109:15-39, 97-126.

Lund, P. W. 1950. Memórias sobre a Paleontologia Brasileira (Revistas e comentadas por Carlos de Paula Couto). Rio de Janeiro, Ministério da Educação e Saúde, Instituto Nacional do Livro, $589 \mathrm{p}$.

MacFadden, B, J. \& Shockey, B. J. 1997. Ancient feeding ecology and niche differentiation of Pleistocene Mammalian herbivores from Tarija, Bolivia: morphological and isotopic evidence. Paleobiology, 23(1):77-100.

Marshall, L. G.; Berta, A.; Hoffstetter, R.; Pascual, R.; Reig, O. A.; Bombin, M. \& Mones, A. 1984. Mammals and Stratigraphy: Geochronology of the continental mammal-bearing Quaternary of South America. Palaeovertebrata - Mémoire Estraordinaire, p.1-76.

Menegaz, A. N. \& Ortiz-Jaureguizar, E. O. 1995. Los Artiodáctilos. In: M. T. Alberdi; G. Leone \& E. P. Tonni (eds.) Evolución biológica y climática de la región Pampeana durante los últimos cinco millones de años. Un ensayo de correlación con el Mediterráneo occidental, CSIC, Monografías del Museo Nacional de Ciencias Naturales, p. 311-337.

Menegaz, A.N.; Goin, F. J. \& Ortiz-Jaureguizar, E. 1989. Análisis morfológico e morfométrico multivariado de los representantes fósiles y vivientes del género Lama (Artiodactyla, Camelidae). Sus implicancias sistemáticas, biogeográficas, ecológicas y biocronológicas. Ameghiniana, 26(3,4):153-172.

Miller, E.T. 1987. Pesquisas arqueológicas paleoindígenas no Brasil Ocidental. Estudios Atacameños, 8: 37-61.

Milder, S. E.S. 2000. Arqueologia do Sudeste do Rio Grande do Sul: Uma Perspectiva Geoarqueológica. Museu de Arqueologia e Etnologia, Universidade de São Paulo, Tese de Doutorado, $172 \mathrm{p}$.

Nomina Anatomica Veterinaria. 1983. Revised by the International Committee on Veterinary Gross Anatomical Nomenclature and autorized by the Twelfth General Assembly of the World Association of Veterinary Anatomists, Mexico, Third Edition, $147 \mathrm{p}$.

Noriega, J.I.; Carlini, A.A. \& Tonni, E.P. 2003. Vertebrados del Pleistoceno tardío de la cuenca del Arroyo Ensenada (Departa- 
mento Diamante, Provincia de Entre Ríos). INSUGEO, Miscelánea, Temas de la Biodiversidad del Litoral Fluvial Argentino, 12:1-6.

Oliveira, E.V. 1992. Mamíferos fósseis do Quaternário do Estado do Rio Grande do Sul, Brasil. Curso de Pós-Graduação em Geociências, Universidade Federal do Rio Grande do Sul, Dissertação de Mestrado, 118 p.

Oliveira, E.V. \& Lavina, E.L. 2000. Mamíferos: Protagonistas dos tempos modernos. In: M. Holz \& L. F. De Ros (eds.) Paleontologia do Rio Grande do Sul, CIGO/UFRGS, p.376394.

Oliveira, E.V. \& Pereira, J.C. 2006. Mamíferos Xenartros do Sistema Lagunar III, Arroio Chuí, Santa Vitória do Palmar, RS, Brasil.Ciência e Natura (Edição Especial):71.

Paula-Couto, C. 1980. Fóssil Pleistocene to Sub-Recent Mammals from Northeastern Brazil. I- Edentata megalonychidae. Anais da Academia Brasileira de Ciências, 52(1):143-151.

Pires-Ferreira, E. 1982. Nomenclatura y nueva classificacion de los camélidos sudamericanos. Revista do Museu Paulista (N. S.), 28:203-219.

Rancy, A. 1993. Sobre a presença de Camelidae na Amazônia Ocidental durante o Pleistoceno. In: CONGRESSO BRASILEIRO DE PALEONTOLOGIA, 13, 1993. Boletim de Resumos, São Leopoldo, p.138.

Ribeiro, A. M.; Drehmer, C.J.; Buchmann, F.S.C. \& Lopes, P.C.S. 1998. Pleistocene skull remains of Pontoporia Blainvillei (Cetacea, Pontoporiidae) from the coastal plain of Rio Grande do sul State, Brazil, and the relationship of pontoporids. Revista da Universidade de Guarulhos, 3(6):71-77.

Rolim, J. L. 1974. Paleontologia e estratigrafia do Pleistoceno continental do Nordeste Brasileiro "Formação Cacimbas". Curso de Pós-Graduação em Geociências, Universidade Federal do Rio Grande do Sul, Dissertação de Mestrado, 110 p.

Salles, L.O.; Guedes, P. G.; Cartelle, C.; Toledo, P.M.; Libertino, A.; Carvalho, G.; Fracasso, M. P.; Garboggini, H.; Cabrali, P. \& Russo, C. A. M. 2003. Quaternary mammals from an underwater cave in Serra da Bodoquena (Brazil). In: LATINAMERICAN CONGRESS OF SEDIMENTOLOGY, 3, 2003. Abstracts, Belém, p. 216-218.

Scherer, C.S. \& Da Rosa, Á.A.S. 2004. Um Eqüídeo Fóssil do Pleistoceno de Alegrete, RS, Brasil. Pesquisas em Geociências, 3(2):33-38.

Scherer, C. S.; Ferigolo, J. \& Ribeiro, A. M. 2004. Sobre os Camelidae (Artiodactyla) do Quaternário do Estado do Rio Grande do Sul, Brasil. Boletim Paleontologia em Destaque, 49:59.
Scherer, C.S.; Ferigolo, J. \& Ribeiro, A. M. 2005. Sobre Palaeolama e Lama (Artiodactyla, Camelidae) no Quaternário do rio Grande do Sul, Brasil. In: CONGRESSO BRASILEIRO DE PALEONTOLOGIA, 19/CONGRESSO LATINO-AMERICANO DE PALEONTOLOGIA, 6, 2005. CD Resumos, Aracaju.

Scherer, C.S.; Ferigolo, J. \& Ribeiro, A.M. 2006. Estudo dos Camelidae (Mammalia, Artiodactyla) do Pleistoceno Superior do Estado do Rio Grande do Sul, Brasil. In: JORNADAS ARGENTINAS DE PALEONTOLOGÍA DE VERTEBRADOS, 22, 2006. Libro de Resúmenes, San Juan, p. 32.

Sisson, S. \& Grossman, J. D. 1963. Anatomia de los Animales Domésticos. $4^{\mathrm{a}}$ ed., Barcelona, Salvat, $952 \mathrm{p}$.

Souza-Cunha, F. L. 1959. Mamíferos fósseis do Pleistoceno do Rio Grande do Sul. I-Ungulados. Rio de Janeiro, Departamento Nacional de Produção Mineral, Divisão de Geologia e Mineralogia, 47 p. (Boletim 202).

Souza-Cunha, F.L. 1966. Explorações Paleontológicas no Pleistoceno do Rio Grande do Norte. Arquivos do Instituto de Antropologia Câmara Cascudo, 2(1,2):75-116.

Tonni, E.P. 1985. Mamíferos del Holoceno del Partido de Lobería, Província de Buenos Aires. Aspectos paleoambientales y bioestratigráficos del Holoceno del sector oriental de Tandilia y area interserrana. Ameghiniana, 22(3-4): 283-288.

Ubilla, M. 2004. Mammalian biostratigraphy of Pleistocene fluvial deposits in Northern Uruguay, South America. Proceedings of the Geologists' Association, 115:347-357.

Ubilla, M. \& Perea, D. 1999. Quaternary vertebrates of Uruguay: A Biostratigraphic and climatic overview. In: J. Rabassa \& M. Salemme (eds.) Quaternary of South America and Antartic Peninsula, A.A. Balkema Publishers, p. 75-89.

Villwock, J. A. \& Tomazelli, L. J. 1995. Geologia Costeira do Rio Grande do Sul. Porto Alegre, Notas Técnicas, Publicação CECO-UFRGS, 45 p. (Boletim 8).

Webb, S. D. 1965. The Osteology of Camelops. Bulletin of the Los Angeles County Museum Science, 1:1-54.

Webb, S.D. 1974. Pleistocene llamas of Florida with a brief review of the Lamini. In: S. D. Webb (ed.) Pleistocene Mammals of Florida, University of Florida Press, p. 170-213.

Webb, S.D. \& Stehli, F. G. 1995. Selenodont Artiodactyla (Camelidae and Cervidae) from the Leisey Shell Pits, Hills Borough County, Florida. Bulletin of the Florida Museum of Natural History, 37(19):621-643.

Winge, H. 1906. Jordgundne og nulevende Hovdyr (Ungulata) fra Lagoa Santa, Minas Gerais, Brasilien. Med udsigt over gumlernes indbyrdes slaegtskab. E Museo Lundii, 3(1):1-239.

Received in October, 2006; accepted in January, 2007. 